\title{
Methodology to Assess Sustainable Mobility in LATAM Cities
}

\author{
José I. Huertas $1, * \mathbb{*}$, Sonja Stöffler ${ }^{2}\left(\mathbb{D}\right.$, Trinidad Fernández ${ }^{3}$, Xanin García ${ }^{4}$, Roberto Castañeda ${ }^{4}$, \\ Oscar Serrano-Guevara ${ }^{1}{ }^{\mathbb{D}}$, Antonio E. Mogro ${ }^{1}{ }^{\mathbb{C}}$ and Duván A. Alvarado ${ }^{1}$ \\ 1 Tecnologico de Monterrey, School of Engineering and Science, Monterrey 64849, Mexico; \\ a00829611@itesm.mx (O.S.-G.); amogro@tec.mx (A.E.M.); duvanalvarado@usantotomas.edu.co (D.A.A.) \\ 2 Institute of Human Factors and Technology Management IAT, University of Stuttgart, \\ 70569 Stuttgart, Germany; sonja.stoeffler@iao.fraunhofer.de \\ 3 Fraunhofer Institute for Industrial Engineering IAO, 70569 Stuttgart, Germany; \\ trinidad.fernandez@iao.fraunhofer.de \\ 4 Instituto Municipal de Planeación Saltillo-IMPLAN, Saltillo 25198, Mexico; xgarcia@implansaltillo.mx (X.G.); \\ rcastaneda@implansaltillo.mx (R.C.) \\ * Correspondence: jhuertas@tec.mx; Tel.: +52-722-100-9417
}

Citation: Huertas, J.I.; Stöffler, S.; Fernández, T.; García, X.; Castañeda, R.; Serrano-Guevara, O.; Mogro, A.E.; Alvarado, D.A. Methodology to Assess Sustainable Mobility in LATAM Cities. Appl. Sci. 2021, 11, 9592. https://doi.org/10.3390/ app11209592

Academic Editor: Paola Pellegrini

Received: 11 August 2021

Accepted: 28 September 2021

Published: 14 October 2021

Publisher's Note: MDPI stays neutral with regard to jurisdictional claims in published maps and institutional affiliations.

Copyright: (c) 2021 by the authors. Licensee MDPI, Basel, Switzerland. This article is an open access article distributed under the terms and conditions of the Creative Commons Attribution (CC BY) license (https:// creativecommons.org/licenses/by/ $4.0 /)$.

\begin{abstract}
As the first step toward implementing strategies to improve mobility in urban centers, governmental authorities must assess their present situation in order to identify the most effective actions that should be included in their short and long-term plans. However, there is not a wellestablished methodology to carry out such an assessment. The already existing ones are subjective, incomplete, costly, and hard to implement, especially for the case of Latin American (LATAM) countries. This paper proposes a comprehensive methodology to carry out this assessment. It uses recent advances in information technologies and includes the use of web map services, telematics data, and low-cost vehicle emission tests. As an example of application, a mobility assessment was carried out for Saltillo, a medium-sized city in northeastern Mexico, which is considered a typical city in LATAM countries. Results indicate that this methodology can be replicated at a low incremental cost and that it leads towards the identification of the most sustainable (economic, environmental, and social) actions that should be implemented in these cities considering their local circumstances.
\end{abstract}

Keywords: smart mobility; smart cities; sustainable transport; telematics; information technology

\section{Introduction}

Industrialization and globalization have triggered people to migrate from the countryside to urban areas. Cities, in response to the pulsating demands for new places to live, expand their area horizontally, creating what is known as urban sprawl. As a consequence, citizens are traveling large distances in their daily life activities, causing problems of transport and traffic. Therefore, there is an urgent need for governments to assess mobility in their cities as a preliminary step to identify the high-impact mobility strategies they need to implement in the short and medium term.

Urban areas are wide regions with complex issues related to individual, collective, and freight mobility. The continuous urban growth around the globe in the last few decades has provoked widespread urban growth with alarming rates of growth rates in the vehicle fleet and their environmental impact [1]. The use of vehicles becomes a problem when meeting air quality standards in urban areas since polluting emissions increase significantly in such places with the number of vehicles and traffic [2]. Consequently, the mobility concept has changed to a sustainable urban mobility concept. Mobility is the ability to move freely. In the context of urban regions, sustainable mobility is the ability of a transport system to meet the needs of its citizens and goods of gaining access to desired locations, with the minimum environmental impact, minimum cost, and means well accepted by the community. This means that mobility is no longer based on the distances and attraction nodes classical model [3]. Now, it is the ability to meet the needs of society to move freely, 
gain extensive access to desired locations, communicate, negotiate, and make relationships without sacrificing other values, today or in the future [4].

Furthermore, the sustainable mobility concept has advanced to the smart mobility concept, along with the concepts of smart city [5], where authorities optimize planning processes and improve the outcomes of those plans, based on the knowledge gained from dynamic data and information gathered in the cloud from large networks of low-cost sensors (monitoring technologies that after a few years have become accessible to the cities at low cost). Evidence-based planning seeks to ensure that planned activities are linked to final outcomes where the best available data, information, and knowledge are used to make decisions. Obtaining scientific evidence to measure the performance of cities as well as to support monitoring and evaluation in certain areas is essential when planning interventions. These evaluations not only allow for an assessment of the current situation but also to measure whether the measures taken have been successful.

Aiming to achieve the previous objective, several efforts have been made to develop methods to evaluate the status of urban mobility in several cities around the globe. Table 1 lists the most relevant and recent studies focused on evaluating urban mobility. Although many of these studies claim to have included a substantial number of cities around the world, most of these studies were developed in European, Asian, and North American cities. In few cases, they included Latin American (LATAM) megacities such as Mexico City and Lima.

Methodologies to assess urban mobility: Based on the previous literature review, Table 2 includes eight methodologies to evaluate urban mobility in cities developed by governmental organizations and private companies, all of them based on the use of performance indicators. Some European organizations, such as the Fraunhofer Society, formed the Morgenstadt Innovation Network and developed a methodology called City Labs that combines quantitative and qualitative assessments. They recognize the city as an extensive complex system and perform a tailored, smart city assessment that includes the following key sectors: energy, mobility, information and communication technologies (ICT), buildings, production and logistics, security, governance, and water infrastructure. They note the importance of working closely with local stakeholders to develop an integrated roadmap of tailored strategies for the city evaluated, considering their local conditions. This methodology has been applied to the cities of Prague, Lisbon, Chemnitz, Tbilisi, and Coimbatore (India) [6]. Within the Morgenstadt Global Smart Cities Initiative (MGI), a project funded by the International Climate Initiative (IKI) from the German Federal Environment Ministry (BMU), implements City Labs aiming to support sustainable urban transformation processes in Kochi in India, Piura in Peru, and Saltillo in Mexico, the latter with a focus on energy, water, and mobility.

Indicators: Most methodologies to assess urban mobility are based on the use of performance indicators. These are parameters that allow the representation and evaluation of a specific phenomenon [7]. For evaluating urban mobility, these indicators should comply with a few common attributes, such as being linked to mobility goals while being easy to interpret and quantify for comparison purposes. Generally, when considering a quantitative analysis, the indicators can be either attributable (yes/no answer) or measurable [8]. 
Table 1. Recent studies focused on assessing urban mobility.

\begin{tabular}{|c|c|c|c|c|c|c|}
\hline \multirow{2}{*}{$\begin{array}{c}\text { Reference } \\
{[9]}\end{array}$} & \multirow{2}{*}{$\begin{array}{c}\text { Index } \\
\text { Impact Mobility Index }\end{array}$} & \multirow{2}{*}{$\begin{array}{c}\text { Study Objective } \\
\text { Connection between } \\
\text { urban expansion and } \\
\text { environmental costs }\end{array}$} & \multicolumn{2}{|c|}{ Criteria } & \multirow{2}{*}{$\begin{array}{c}\text { Indicators } \\
18\end{array}$} & \multirow{2}{*}{$\begin{array}{c}\text { Region } \\
\text { Italy }\end{array}$} \\
\hline & & & $\begin{array}{l}\text { (1) Geographical } \\
\text { variables } \\
\text { (2) Socio-economic } \\
\text { variables }\end{array}$ & $\begin{array}{l}\text { (3) Morphology } \\
\text { (4) Accessibility and } \\
\text { transport efficiency }\end{array}$ & & \\
\hline [10] & $\begin{array}{l}\text { Sampling Mobility } \\
\text { Index }\end{array}$ & $\begin{array}{l}\text { Mobility for } \\
\text { medium-size cities } \\
\text { urban centers }\end{array}$ & $\begin{array}{l}\text { (1) Pedestrians } \\
\text { (2) Motor vehicles }\end{array}$ & (3) Cycling & 8 & Brazil \\
\hline [11] & $\begin{array}{c}\text { Sustainable Urban } \\
\text { Mobility Index (IMUS) }\end{array}$ & $\begin{array}{l}\text { Mobility Planning } \\
\text { and management } \\
\text { supporting tool }\end{array}$ & $\begin{array}{l}\text { (1) Accessibility } \\
\text { (2) Environmental } \\
\text { Aspects } \\
\text { (3) Social Aspects } \\
\text { (4) Political Aspects } \\
\text { (5) Transportation } \\
\text { infrastructure } \\
\text { (6) Non-motorized } \\
\text { modes }\end{array}$ & $\begin{array}{l}\text { (7) Integrated } \\
\text { planning } \\
\text { (8) Urban circulation } \\
\text { and traffic } \\
\text { (9) Urban transport } \\
\text { system }\end{array}$ & 87 & Brazil \\
\hline [12] & $\begin{array}{l}\text { Sustainable Urban } \\
\text { Mobility Index (IMS) }\end{array}$ & $\begin{array}{l}\text { Evaluate the impact of } \\
\text { mobility on the } \\
\text { sustainability of the city }\end{array}$ & $\begin{array}{l}\text { (1) Social } \\
\text { (2) Economic }\end{array}$ & (3) Environment & 10 & Brazil \\
\hline [13] & $\begin{array}{l}\text { Normalized Transport } \\
\text { Sustainability Index }\end{array}$ & $\begin{array}{l}\text { Cluster policies of } \\
\text { sustainable mobility }\end{array}$ & $\begin{array}{l}\text { (1) Budget } \\
\text { (2) Planning and } \\
\text { land-use } \\
\text { (3) Safety }\end{array}$ & $\begin{array}{l}\text { (4) Time } \\
\text { (5) Health and } \\
\text { environment } \\
\text { (6) Social }\end{array}$ & 24 & Europe \\
\hline [14] & $\begin{array}{l}\text { Composite } \\
\text { Sustainability Index } \\
\text { (CSI) tool }\end{array}$ & $\begin{array}{c}\text { Evaluate transportation } \\
\text { and land } \\
\text { use alternatives }\end{array}$ & $\begin{array}{l}\text { (1) Environmental } \\
\text { Sustainability } \\
\text { (2) Socio-cultural } \\
\text { sustainability }\end{array}$ & $\begin{array}{l}\text { (3) Transport system } \\
\text { effectiveness } \\
\text { (4) Economic } \\
\text { sustainability }\end{array}$ & 30 & US \\
\hline [15] & $\begin{array}{l}\text { Urban Sustainable } \\
\text { Transportation } \\
\text { Indicators }\end{array}$ & $\begin{array}{l}\text { For global comparison } \\
\text { based on UITP database }\end{array}$ & $\begin{array}{l}\text { (1) Environmental } \\
\text { (2) Economical }\end{array}$ & (3) Social & 9 & World \\
\hline [16] & Urban Core Index (UCI) & $\begin{array}{c}\text { Standardize } \\
\text { classification of urban } \\
\text { and suburban census } \\
\text { tracts }\end{array}$ & (1) Urban Census & & 3 & Canada \\
\hline [17] & $\begin{array}{l}\text { Transport Sustainability } \\
\text { Index }\end{array}$ & $\begin{array}{l}\text { Obtaining a composite } \\
\text { transport sustainability } \\
\text { index for Australia }\end{array}$ & $\begin{array}{l}\text { (1) Environmental } \\
\text { (2) Social }\end{array}$ & (3) Economical & 9 & Australia \\
\hline [18] & $\begin{array}{l}\text { Urban mobility index } \\
\text { (UMI) }\end{array}$ & $\begin{array}{l}\text { Introduction of an } \\
\text { urban mobility measure } \\
\text { using a point system }\end{array}$ & $\begin{array}{r}\text { (1) Correlated with the } p \\
\text { private moto }\end{array}$ & $\begin{array}{l}\text { zentage of daily trips of } \\
\text { zed modes }\end{array}$ & 19 & $\begin{array}{l}\text { US and } \\
\text { Hong Kong }\end{array}$ \\
\hline [8] & $\begin{array}{l}\text { Synthetic Indicator of } \\
\text { Smart Mobility (SMI) }\end{array}$ & $\begin{array}{l}\text { Construction of a } \\
\text { Synthetic Indicator of } \\
\text { Urban Mobility }\end{array}$ & $\begin{array}{l}\text { (1) Public transport } \\
\text { (2) Cycle lanes } \\
\text { (3) Bike-sharing } \\
\text { (4) Car sharing } \\
\text { (5) Private mobility } \\
\text { support system }\end{array}$ & $\begin{array}{l}\text { (6) Public transport } \\
\text { support system }\end{array}$ & 18 & Italy \\
\hline [19] & Smart Mobility Index & $\begin{array}{l}\text { benchmarking cities in } \\
\text { accordance with the } \\
\text { smartness of their } \\
\text { transportation systems }\end{array}$ & $\begin{array}{l}\text { (1) Sustainability: } \\
\text { - Social transportation } \\
\text { - Environmental } \\
\text { - Economic }\end{array}$ & $\begin{array}{l}\text { (2) Innovation: } \\
\text { - Technological }\end{array}$ & 16 & Spain \\
\hline [20] & $\begin{array}{l}\text { Sustainable Mobility } \\
\text { Efficiency Index (SMEI) }\end{array}$ & $\begin{array}{l}\text { Enhancing the } \\
\text { Sustainable Urban } \\
\text { Mobility in Greek Cities }\end{array}$ & $\begin{array}{l}\text { (1) Accessibility and } \\
\text { operation of the } \\
\text { transport system } \\
\text { (2) Environment }\end{array}$ & $\begin{array}{l}\text { (3) Society } \\
\text { (4) Economy } \\
\text { (5) Transport system } \\
\text { quality }\end{array}$ & 15 & Greece \\
\hline
\end{tabular}

Tables 1 and 2 state the criteria used to set up the performance indicators according to the objective pursued in each study or methodology. Since the majority were carried out in Europe, these indicators are aligned to the European Union policies of sustainable mobility [13] and even include innovation as a fourth pillar [19]. Many urban mobility studies consider indicators based solely on the three pillars of sustainability: the economy, society, and environment $[12,14,15,17,19]$. However, the indicators used mainly depend on the characteristics of the region considered and the objective sought in each study. Some of them included additional pillars such as innovation, connectivity, maturity, and even preparedness for the future. For instance, [9] proposed indexes to evaluate the impact of land usage and mobility on different patterns of urban expansion in the metropolitan area of Milan, Italy. The objective of their study led them to consider not only socioeconomic variables but also to include geographical and morphological variables. Similarly, other studies have chosen their indicators based on the size of the city [10], policies impact [13,21] ease of implementation [22], data availability [16], and even on the impact of implementing 
the use of autonomous electric vehicles [23]. Ref. [24] examined thirty-four different mobility assessment indicators and highlighted the importance of including more than one evaluating aspect at the same time when assessing the sustainability and smartness of a city. This study concluded that this kind of evaluation must be done continuously as different improvement strategies are implemented. Aiming to achieve this task, it is essential to guarantee access to big data and real-time data. In the case of the MGI project, part of the research included an adaptation of the methodology to the context of the participating cities, thus providing a parameter for comparison with cities in developing countries [6].

As mentioned above, there are mobility indexes or indicators proposed by government entities [25], organizations [25,26], and private companies [27-31]. Details of some of these mobility indexes can be found in Tables 1 and 2.

Table 2. Indicators used by government and private companies to assess urban mobility.

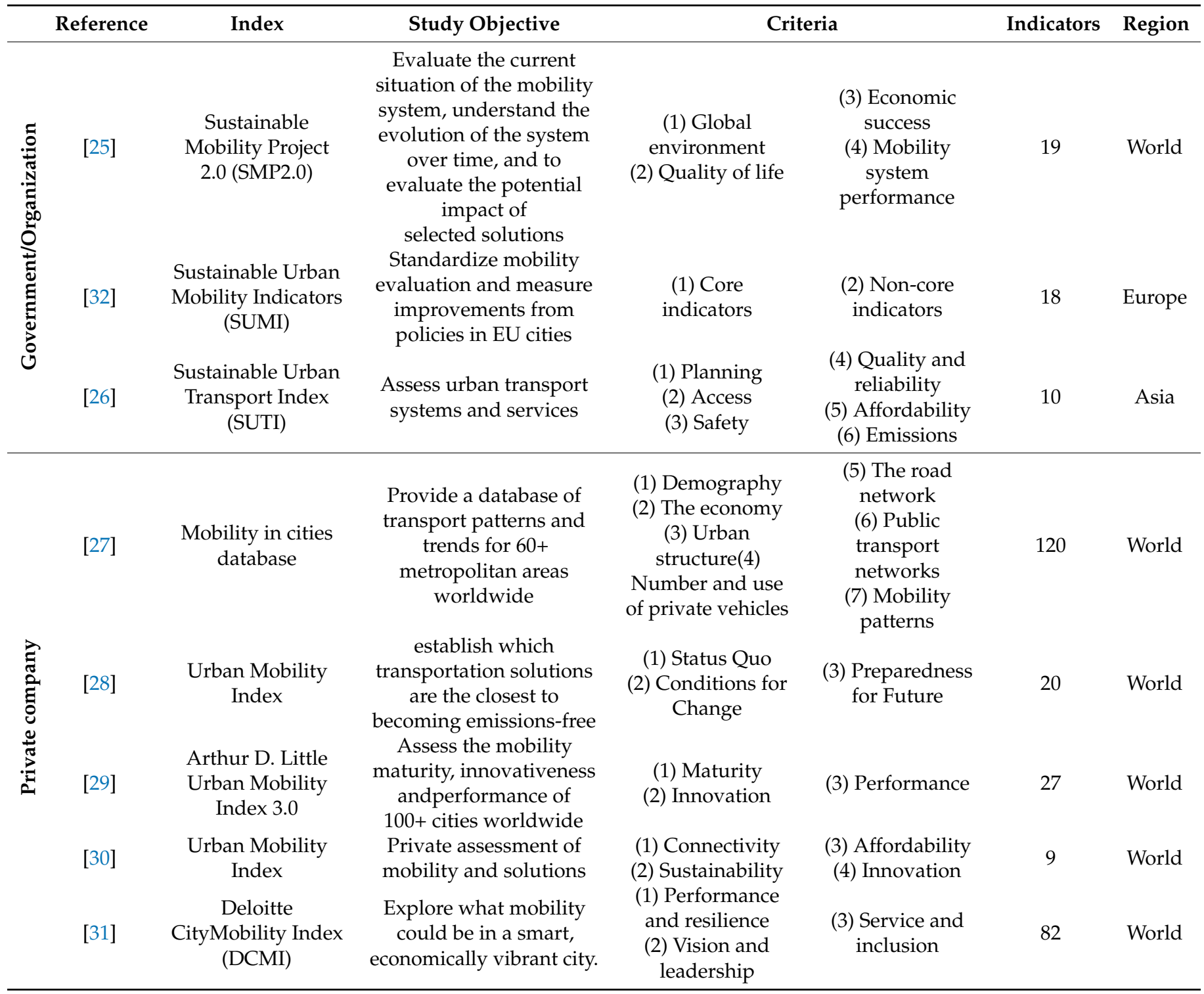

It is important to mention that not every mobility study aims to identify the best set of indicators for a given application. For example, Moeinaddini et al. [18] evaluated private motorized trips at the city level by introducing urban mobility indicators that, when standardized and evaluated, correlate the sustainability of the mobility system of various cities to a percentage of daily trips made through private motorized modes. However, they 
did not suggest new sets of indicators but used a set of indicators already established and measured by the Union Internationale des Transports Publics (UITP) in 60 metropolitan areas around the world. Another example is the MGI project, with an objective to support the climate change adaptation of participating cities as well as to promote sustainable urban transformations, where mobility is considered a major driver of change.

Need: In summary, most studies have assessed urban mobility based on quantitative and qualitative indicators, and they evaluate the mobility of the city of interest by comparing those local indicators with the reported for other cities. However, these works do not fully describe the process to obtain representative values for those indexes. There is still little available information and a lack of transparency on the mobility assessment schemes used. The low level of replicability of the assessment schemes used in some studies, as well as the use of information focused mostly on developed countries, limits their application to LATAM countries.

Table 2 shows that the few studies carried out in developing countries still focused with broader importance on motorized vehicles [10] and included infrastructure and political aspects [6,11]. Additionally, the list of indicators used in the already evaluated cities is limited and, in some cases, obtainable through a membership fee [27] or consultancy assessment [28]. These circumstances result in limited information for benchmarking medium-sized LATAM cities.

Marchetti et al. [33], concluded that models developed in Europe, the United States, or Canada to assess sustainability in any aspect are not designed to capture the existing inequalities in LATAM because they do not have the potential to consider local particularities. Even small differences found in LATAM socioeconomic characteristics directly influence the way in which people move from one place to another [34]. To address LATAM mobility, Altamirano-Avila and Martínez [35] carried out a study in five LATAM cities using the Sustainable Development of Energy, Water, and Environment Systems (SDEWES) index, which was developed by a non-governmental and a non-profit scientific organization based in Croatia. As in many other similar cases, when applying a European sustainability index, Altamirano-Avila and Martínez had complications when using the 35 indicators proposed by SDEWES since these were based on data publicly available in the Sustainable Energy Action Plans (SEAP) that are carried out on European cities.

LATAM cities have unique characteristics that induce needs of transport which are different from other regions. Cities are highly populated, unplanned, spread, and usually located in mountainous regions. Cities are highly stratified, with people with the lowest income living on the outskirts of the city. Consequently, the working class must travel long distances for work. Railway systems have not been considered an appropriate mode of transportation for these cities located in mountainous regions. Thus, mobility in LATAM cities is based on diesel-fueled buses. Metro, subways, and trains are rare. The use of bicycles as an alternative mode of transportation just started to emerge in the main cities. The transportation of people has been dominated by a few private companies that have a very strong political power. The participation of people in mobility-related decisions is negligible.

Under these circumstances, the straight use of the methodologies reported in the literature to assess mobility in LATAM cities could result erroneously in transport systems with high scores in terms of urban mobility. For example, when compared with European cities, the LATAM transport system based on buses exhibits excellent performance in cost per $\mathrm{km}$ traveled, and average distances traveled. However, LATAM transport systems are frequently socially unacceptable because the service is scarce, with low coverage, and based on highly polluting outdated buses. Furthermore, the straight use of these methodologies could mislead the decision-making process of governmental authorities, who usually have ended up concentrating their resources in new roads for private vehicles when the root cause of mobility problems could be the city's distribution.

This work: This work advances the mobility section of the Morgenstadt methodology to perform smart city assessments and proposes a comprehensive methodology that takes 
into consideration the characteristics of mobility in LATAM cities. The aim of the proposed methodology is to identify strategies that contribute substantially to improve mobility, reduce energy consumption and tailpipe emissions. The methodology includes the analysis of pillars and categories that influence these three aspects of the transport system under study. Therefore, root causes are connected to observable metrics, which key information in the process of identifying strategies to improve in any of those aspects. An additional innovative aspect of the proposed methodology is that it includes the use of information technology to evaluate performance indicators. We propose the use of data obtained from telematic systems, web mapping services, air quality networks, and inspection and maintenance I/M programs. The manuscript describes the data analysis that needs to be carried out oriented toward the evaluation of those performance indicators.

Section 2 will describe the proposed methodology, and Section 3 will present the results obtained implementing this methodology on Saltillo, a medium-sized city in LATAM, as an illustrative case. The main issues observed using the methodology proposed will be presented in Section 4 and the final remarks in Section 5.

\section{Methodology}

The main purpose of the proposed methodology is to facilitate the identification of strategies to improve sustainable mobility, reduce energy consumption, and tailpipe emissions in the urban center of interest. This methodology is based on the Morgenstadt methodology to assess smart cities and results on urban mobility obtained by the City Lab team composed by the University of Stuttgart IAT, Fraunhofer Institute for Industrial Engineering IAO, Tecnológico de Monterrey, and the Municipal Planning Institute (IMPLAN) Saltillo in the city of Saltillo, Mexico. The methodology was designed to allow the participation of third parties that could not be well informed on the local particularities of the city. Therefore, this methodology includes the documentation of the current situation of the city on the many aspects connected to the mobility of the city.

The proposed methodology is divided into three phases (Figure 1): (i) Describing the region of study, (ii) obtaining local data to evaluate mobility-related performance indicators, and (iii) performing a mobility assessment based on a benchmarking evaluation of Key Performance Indicators (KPIs) with comparable and/or reference cities. Next, each of these phases will be described.

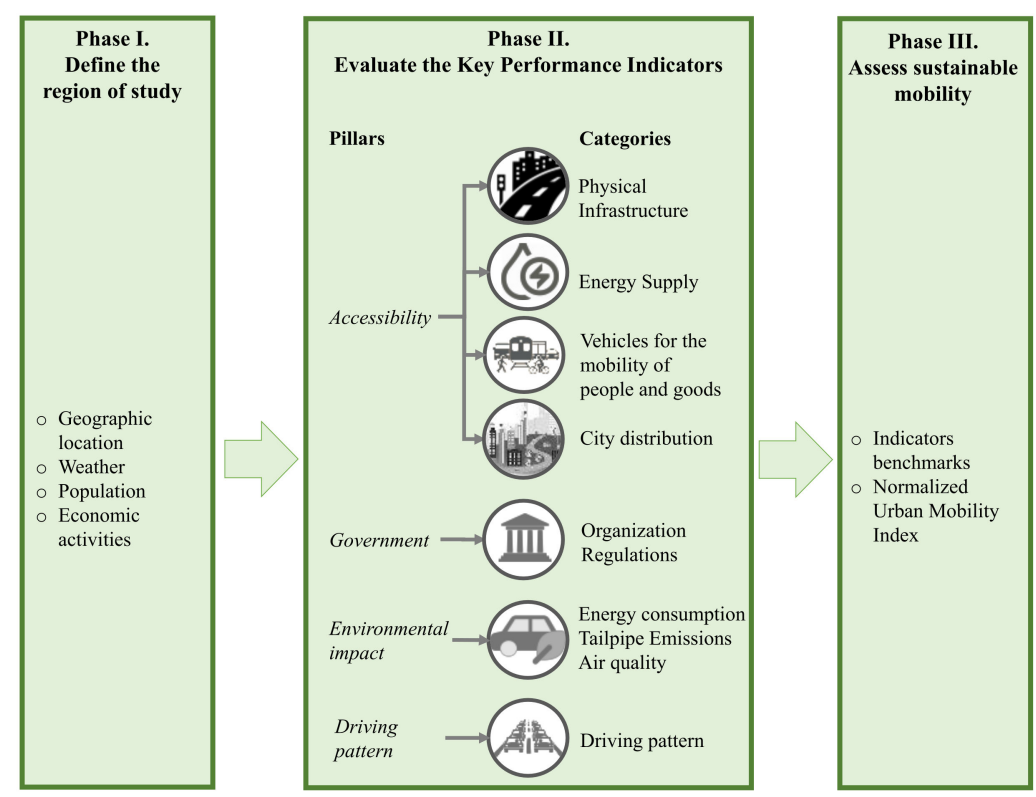

Figure 1. Illustration of the phases to be followed in the proposed methodology to assess sustainable urban mobility. 


\subsection{Region of Study}

In the first phase, the main characteristics of the city are described aiming to provide a frame of reference for the local conditions. The mobility of an urban area widely depends on its local conditions (topography, weather, demography, and economy). The geographical location has an important influence on variables such as topography and prevalent weather conditions. Furthermore, it is associated with the cultural aspects of the region. In the same way, weather influences traffic, accidents, the inter modality of transport (e.g., bicycle, vehicle, bus, etc.), the vehicle configuration (i.e., use of air conditioning), and public policies implemented (e.g., fuel composition). Information on the surface area, number of inhabitants, and vehicle fleet should be included. The main economic activities and average income per capita are also relevant. Places within the city, which are the main originator or attractor of trips, should be identified.

\subsection{Evaluation of Mobility-Related Performance Indicators}

The present methodology is based on four pillars (Accessibility, Government, Environmental impact, and Mobility patterns) and several categories per pillar, which are illustrated in Figure 1. Each category is evaluated through a set of mobility-related performance indicators. In this second phase, the evaluation of those indicators is performed.

A three-step procedure was used for the identification of the most appropriate indicators per category. In the first step, indicators were collected for every category from an extensive literature review on methodologies carried out by independent studies, government and organizations, private companies, and especially from the Morgenstadt Global Smart Cities Initiative [6].

In the second step, the minimum set of indicators to evaluate each category were selected. Indicators that could be obtained as a derivation from other indicators were removed. For example, average traveling time can be obtained from average speed, and average distance traveled. Indicators that provide a holistic evaluation and are easy to evaluate in an objective way were favored. For example, traffic congestion was computed as the average of $\left(1-v / v_{\max }\right)$, where $v$ and $v_{\max }$ are the average speed and speed limit at each location. This metric was selected instead of the level of service (LoS) metric, which requires the use of an evaluator opinion. Considering the aforementioned factors, a total of 45 indicators were considered in this work (Table 3). They may differ depending on the availability of data for the region of study.

Finally, in the third step, the key performance indicators (KPIs) for each category were identified. They are indicators that: (i) provide a holistic evaluation per category, (ii) identify elements that affect sustainable mobility (social, economic, and environmental impact), (iii) take into consideration the special characteristics found in LATAM cities, and (iv) are easy to evaluate in an objective way using information that is accessible under the LATAM cities context.

In the following subsections, each pillar will be addressed to determine which category and indicators are important for the case of LATAM cities. 
Table 3. Performance indicators, lower and upper benchmarks for key performance indicators $\left(K P I_{i}^{-}\right.$and $\left.K P I_{i}^{+}\right)$, and normalized $K P I_{i}\left(S_{i}\right)$.

\begin{tabular}{|c|c|c|c|c|c|c|c|c|}
\hline Pillar & Category & & Performance Indicators (PIs) & Units & $K P I_{i}$ & $K P I_{i}^{-}$ & $\mathrm{KPI}_{i}^{+}$ & $S_{i}(\%)$ \\
\hline \multirow{22}{*}{ 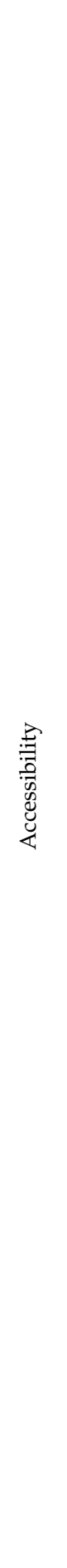 } & \multirow{8}{*}{ Physical Infrastructure } & 1. & Length of the road network* & $\mathrm{km} / 10^{6} \mathrm{hab}$ & 41.2 & 2.84 & 58.6 & 31.2 \\
\hline & & 2. & Length of lanes for public transport & $\mathrm{km} / \mathrm{ha}$ & 0.00 & NR & NR & NR \\
\hline & & 3. & Length of rails transport & $\mathrm{km} / \mathrm{ha}$ & $\mathrm{N} / \mathrm{D}$ & NR & NR & NR \\
\hline & & 4. & Length of the roads for bicycles & $\mathrm{km} / 10^{6} \mathrm{hab}$ & 0.47 & 0.16 & 7.8 & 4.1 \\
\hline & & 5. & $\begin{array}{l}\text { City blocks with pedestrian accessibil- } \\
\text { ity }\end{array}$ & $\%$ & 55.24 & 0 & 100 & 55.2 \\
\hline & & 6. & City blocks with wheelchair ramps & $\%$ & 2.58 & 0 & 100 & 2.6 \\
\hline & & 7. & $\begin{array}{l}\text { Semaphored intersections with de- } \\
\text { fined pedestrian crossings }\end{array}$ & $\%$ & 5.00 & NR & NR & NR \\
\hline & & 8. & Roads in good condition & $\%$ & 10.00 & 0 & 100 & 0.00 \\
\hline & \multirow{3}{*}{ Economic scope } & 9. & $\begin{array}{l}\text { Transportation affordability (Per- } \\
\text { centage of household expenditure } \\
\text { on transport) }\end{array}$ & $\%$ & 19 & 2.8 & 25 & 27 \\
\hline & & 10. & Gross domestic product per capita & USD/hab & 32,000 & 6000 & 70,000 & 40.7 \\
\hline & & 11. & Public transport fee & USD/trip & 0.55 & 0.20 & 2.80 & 87.7 \\
\hline & \multirow{2}{*}{ Energy Supply } & 12. & Number of gas stations & stations $/ 10^{6} \mathrm{hab}$ & 1.2 & 0.1 & 4.3 & 27.0 \\
\hline & & 13. & Number of EV charging stations & $\mathrm{km} / 10^{6} \mathrm{hab}$ & 0.09 & 0 & 5.5 & 1.5 \\
\hline & \multirow{6}{*}{$\begin{array}{l}\text { Vehicles for the mobility } \\
\text { of people and goods }\end{array}$} & 14. & Private vehicles per habitant * & veh/hab & 0.18 & 0.05 & 0.70 & 79.7 \\
\hline & & 15. & $\begin{array}{l}\text { Equivalent public transport vehicles } \\
\text { per habitants }\end{array}$ & veh $/ 10^{6}$ hab & 1232.89 & NR & NR & NR \\
\hline & & 16. & Percentage of motorcycles & $\%$ & $\mathrm{~N} / \mathrm{D}$ & NR & NR & NR \\
\hline & & 17. & Percentage of +10 -year-old vehicles * & $\%$ & 67 & 0 & 100 & 33 \\
\hline & & 18. & $\begin{array}{l}\text { Percentage of hybrid or electric vehi- } \\
\text { cles }\end{array}$ & $\%$ & $<0.01$ & 0 & 17 & 0.00 \\
\hline & & 19. & Percentage of taxicabs & $\%$ & $\mathrm{~N} / \mathrm{D}$ & NR & NR & NR \\
\hline & \multirow{3}{*}{ City distribution } & 20. & Urban density * & [hab/ha] & 48.89 & 13.7 & 286 & 87.08 \\
\hline & & 21. & $\begin{array}{l}\text { Percentage of urban area with ac- } \\
\text { cessibility (5-min walk) to public } \\
\text { transport stations }\end{array}$ & [\%] & 16.40 & 0 & 100 & 0.00 \\
\hline & & 22. & $\begin{array}{l}\text { Number of } \\
\text { cial/administrative } \\
\text { per habitant }\end{array}$ & {$\left[1 / 10^{6} \mathrm{hab}\right]$} & 1.2 & NR & NR & NR \\
\hline
\end{tabular}


Table 3. Cont.

\begin{tabular}{|c|c|c|c|c|c|c|c|c|}
\hline Pillar & Category & & ormance Indicators (PIs) & Units & $K P I_{i}$ & $K P I_{i}^{-}$ & $\mathrm{KPI}_{i}^{+}$ & $S_{i}(\%)$ \\
\hline \multirow{6}{*}{ 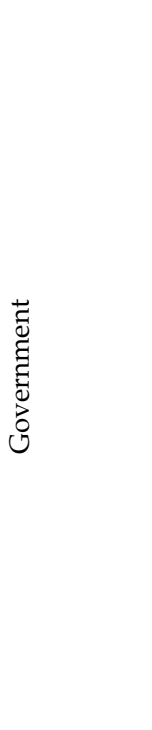 } & \multirow{6}{*}{$\begin{array}{l}\text { Organization and } \\
\text { regulations }\end{array}$} & 23. & $\begin{array}{l}\text { Existence of regulatory } \\
\text { mobility organisms }\end{array}$ & {$[0 / 1]$} & 1 & 0 & 1 & 100 \\
\hline & & 24. & $\begin{array}{l}\text { Participation of civil } \\
\text { organizations and com- } \\
\text { munities related to } \\
\text { sustainable mobility }\end{array}$ & {$[0 / 1]$} & 1 & 0 & 1 & 100 \\
\hline & & 25. & $\begin{array}{l}\text { Presence of public poli- } \\
\text { cies/regulations related } \\
\text { to mobility }\end{array}$ & {$[0 / 1]$} & 1 & 0 & 1 & 100 \\
\hline & & 26. & Existence of I/M program & {$[0 / 1]$} & 1 & 0 & 1 & 100 \\
\hline & & 27. & $\begin{array}{l}\text { Existence of an emissions } \\
\text { regulation for brand new } \\
\text { vehicles }\end{array}$ & {$[0 / 1]$} & 1 & 0 & 1 & 100 \\
\hline & & 28. & $\begin{array}{l}\text { Existence of strategies un- } \\
\text { der implementation for } \\
\text { improving urban mobility }\end{array}$ & {$[0 / 1]$} & 1 & 0 & 1 & 100 \\
\hline \multirow{5}{*}{ 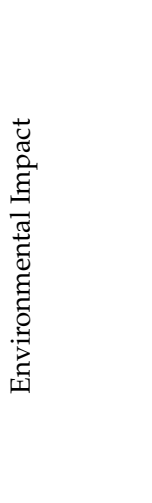 } & \multirow{5}{*}{ Energy and emissions } & 29. & $\begin{array}{l}\text { Average Specific Fuel } \\
\text { Consumption * }\end{array}$ & $1 / 100 \mathrm{~km}$ & 12 & 9.9 & 20.2 & 79.3 \\
\hline & & 30. & $\begin{array}{l}\mathrm{CO}_{2} \text { vehicle emissions } \\
\text { per capita * }\end{array}$ & tons/hab-year & 6.2 & 0.1 & 8.8 & 31.4 \\
\hline & & 31. & $\begin{array}{l}\text { Average } \\
\text { tailpipe concentration }\end{array}$ & $\%$ & 0.58 & 0.06 & 0.6 & 2.8 \\
\hline & & 32. & $\begin{array}{l}\text { Average } \mathrm{HC} \\
\text { tailpipe concentration }^{1, *}\end{array}$ & ppm & 398 & 39 & 506 & 23.1 \\
\hline & & 33. & $\begin{array}{l}\text { Average } \quad \mathrm{NO} \\
\text { tailpipe concentration }\end{array}$ & ppm & 595 & 62 & 596 & 0.2 \\
\hline \multirow{12}{*}{$\begin{array}{l}\frac{2}{7} \\
\frac{1}{0} \\
\sum_{2}^{0}\end{array}$} & \multirow{12}{*}{ Mobility patterns } & 34. & $\begin{array}{l}\text { Vehicle average speed } \\
\text { on weekdays }\end{array}$ & $\mathrm{km} / \mathrm{h}$ & 21.1 & 9.6 & 35 & 45.3 \\
\hline & & 35. & $\begin{array}{l}\text { Vehicle average } \\
\text { positive acceleration }\end{array}$ & $\mathrm{m} / \mathrm{s}^{2}$ & 0.2 & NR & NR & NR \\
\hline & & 36. & Vehicle idling percentage & $\%$ & 21.4 & NR & NR & NR \\
\hline & & 37. & $\begin{array}{l}\text { Average speed/speed } \\
\text { limit }\end{array}$ & $\%$ & 79 & NR & NR & NR \\
\hline & & 38. & Traffic fatalities * & Deaths $/ 10^{6}$ hab & 0.5 & 0.01 & 1.4 & 64 \\
\hline & & 39. & Annual trips per capita & trip/hab-year & 186.5 & 106 & 4131 & 2 \\
\hline & & 40. & Trips by walking & $\%$ & 18 & 6.2 & 51.4 & 26.1 \\
\hline & & 41. & Trips by bike & $\%$ & 0.92 & 0.2 & 32 & 2.3 \\
\hline & & 42. & Trip by public transport & $\%$ & 34 & 4.8 & 51.6 & 62.6 \\
\hline & & 43. & Trip by private vehicle * & $\%$ & 38.1 & 12 & 85 & 64.3 \\
\hline & & 44. & $\begin{array}{l}\text { Travel time } \\
\text { private vehicle * }\end{array}$ & $\min$ & 25.6 & 14 & 32 & 35.6 \\
\hline & & 45. & $\begin{array}{l}\text { Travel time } \\
\text { public transport * }\end{array}$ & $\min$ & 39.5 & 37 & 87 & 95 \\
\hline
\end{tabular}




\subsubsection{Accessibility}

The accelerated expansion of urbanization has had consequences associated with infrastructure, air quality, and the quality of life of residents. Unfortunately, this process leads to a vicious circle in which the expansion of infrastructure stimulates urban growth towards the periphery, increasing car dependency, which in turn requires additional infrastructure development to ease accessibility [36]. Therefore, at this stage of the proposed methodology, an assessment of infrastructure available in the city for the people to access the different places of the city should be performed. Four major areas have been considered: physical infrastructure, energy supply, vehicles for the mobility of people and goods, and city distribution.

Physical infrastructure: This phase aims to describe the physical infrastructure available for the people to move around the city and for the distribution of goods within the city per area of the city and per habitants. Within urban growth, the road conditions and infrastructure available define the ease of mobility between activities and locations. Having accessible infrastructure is a common feature of a sustainable mobility system, as it supports the movement of people and goods by several modes of transport [37]. So, for its evaluation, methods such as audits, surveys, video cameras, or checklists are used to collect information and evaluate urban mobility. However, these methods show shortcomings regarding costs and time [34]. Usually, government entities publish reports on the city's physical infrastructure. They describe the composition of the road network. However, for analyzing the current state of this infrastructure, a diagnosis should be performed through a combination of the data obtained from Geographic Information Systems (GIS) and online map services (WMS). This technique uses the cartographic representation of a city which is then matched with Google Maps tool Google Street View. For the analysis, a broad sample of randomly selected locations around the urban region must be considered to diagnose the roads in terms of:

- $\quad$ Road type

- Pavement material

- damage to the road

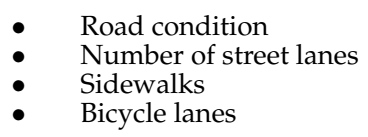

- Traffic lights

- Speed reducerss

- Street sign condition

- Average speed

Energy supply: Within on-road transportation, the energy supply can be considered a basic need, and therefore it is a key measure to identify its accessibility within an urban region. To describe the source of energy available in the city for powering vehicles, it is not only necessary to determine the infrastructure density but also their location (gas stations and electric chargers per habitant and city area). This will allow an assessment of the infrastructure distribution. This information is generally of public domain, or it can be estimated through online map services such as Google Maps. Additionally, a description of the physico-chemical characteristics of the fuel distributed within the city allows identifying if the available fuel quality contributes to excessive vehicle emissions and, therefore, the need for more restrictive fuel quality regulations.

Vehicles for the mobility of people and goods: It is important to describe vehicle fleet composition (type, age, and powering energy) along with the public transport system. Normally, to determine the fleet composition, it is necessary to have access to the local database of registered vehicles in the city, which can be obtained through the local governmental or municipal entity in charge of transportation. Nevertheless, a Remote Sensing Device (RSD) monitoring campaign is recommended. Nowadays, it can be performed at a relatively low cost. It not only allows correlating each vehicle model with their emissions (Section 2.2.3) but also helps to determine the fleet composition of circulating vehicles.

City distribution: A description of how the city is organized is relevant. It should consider population density per administrative county. It also should include the location of the main trip attractors (e.g., airports, malls, stadiums, hospitals, schools), which can be obtained via interviews with a representative sample of the population and the use of information technology that can provide this information at a relatively low cost through the use of tools like Google, Waze, or taxis services such as Uber. 


\subsubsection{Government}

Understanding the government structure could facilitate the introduction of new strategies to improve mobility in the city. Therefore, in this step, a description of the government structure related to mobility, the regulations and strategies implemented, and the civil organizations engaged in the promotion of non-motorized mobility should be provided.

\subsubsection{Environmental Impact}

In this phase, an assessment of the urban air quality is performed in connection with the main sources of air pollutants. An analysis regarding on-road vehicles' energy consumption and emissions is essential since they are the most important source of pollution in urban areas [1]. This step results in high importance when evaluating sustainable mobility. Usually, cities have a network of air quality stations for this purpose. Otherwise, the use of low-cost air quality sensors such as purple air [38] can be used for this purpose. Currently, environmental authorities have metrics and methods to grade the air quality in their cities [39].

Energy consumption: Analyzing the total of energy consumed by a city by vehicles in a year would be subject to a greater influence on the size of the city than on the performance of their vehicles. Therefore, a better approach is to consider only the vehicle average Specific Energy Consumption $\left(S E C_{i, j}\right)$ or Specific Fuel Consumption $\left(S F C_{i, j}\right)$. For electric-powered vehicles, $S E C_{i, j}$ is the energy that vehicles of model $i$ and model-year $j$ consume while being used, and it is expressed as kWh per kilometer driven. For fuel-powered vehicles, energy consumption can be obtained by the liters of fuel consumed per kilometer driven $\left(S F C_{i, j}\right)$ multiplied by the fuel's low-heating value $\left(L H V_{f}\right)$ as expressed in Equation (1). Aiming to compare the energy consumed by fuel-powered vehicles with electric-powered vehicles, Equation (1) must be multiplied by the thermal efficiency of the thermal power plant $\left(\eta_{t h}\right)$ that convert chemical energy into electric energy (known as power plant factor). That factor is around 35\% [40]. In this case, SEC should be named as equivalent specific electric energy consumption.

$$
S E C_{i, j}=S F C_{i, j} L H V_{f} \eta_{t h}
$$

To determine the vehicle $S F C$, the average values reported by vehicle manufacturers of the circulating vehicles (per each model and model year) may be considered. However, it is of major interest their real-world energy consumption. The latter approach allows the inclusion of the effect of local conditions such as age deterioration, mechanical condition, driving patterns, among others. Common strategies to measure real-world fuel consumption on a representative sample of vehicles are: (i) measuring the fuel's weight before and after a specific distance driven (gravimetric method), (ii) measuring instantaneous fuel consumption through the On-Board Diagnostic system (OBD method), and (iii) surveying the SFC reported by the vehicles in their dashboard. We recommend the second alternative, which nowadays can be obtained through third companies that provide this service using telematic systems. A detailed description of the measurement of fuel/energy consumption can be found in [41-43].

Vehicles' emissions: An emissions inventory of the anthropogenic emissions is a strategic tool that reports the type and quantity of pollutants that are emitted into the atmosphere by the different sectors. It is essential for the design of actions aimed at the mitigation, adaptation, and control of urban air quality. It identifies the sectors that should be addressed to obtain the highest impact on air quality improvement. However, it requires the measurement of the local on-road emissions to obtain accurate results. The technique used for measuring these emissions, together with the criteria selected for the vehicles sample and measurement conditions, has a great impact on the representativeness of the emissions obtained in each city or country. The most common methodologies to measure on-road emissions can be synthetized in two categories [44]: (i) Fleet-basis emissions techniques, such as Tunnel studies [45], and (ii) Individual-basis emissions techniques such as RSD [46] 
and Portable Emissions Measurement System (PEMS) [42]. When assessing sustainable mobility in a region, it would be desirable to measure the vehicles under representative driving conditions using the most accurate technology available (e.g., PEMS). However, its high cost of acquisition and use makes this technique only feasible on a very small sample of vehicles, reducing the representativeness of the effect of the local conditions on their emissions. Since the latter part is of great importance when evaluating fleetwide, the RSD technique is more appropriate. This technique sacrifices the ability to include typical driving conditions but allows the inclusion of a more representative sample of vehicles. An RSD campaign allows the simultaneous determination of the fleet composition and emissions of circulating vehicles. It allows the connection between the vehicle fleet composition and their corresponding emissions [47]. Furthermore, it can be used as part of the city's Inspection and Maintenance (I/M) programs [48-51]. Considering the aforementioned circumstances, we recommend an RSD monitoring campaign as part of the urban mobility assessment.

\subsubsection{Mobility}

In this section, mobility is explicitly evaluated. Mobility encompasses how vehicles are being driven in a city, which is directly connected to the intermodality of transportation, traffic congestion, and driving patterns. For the intermodality of transportation, it is relevant to identify the preference of commuters for each mode of transportation.

For traffic congestion, the Level of Service (LoS) is a known qualitative metric frequently used. It is a categorization of the roadways in terms of traffic flow which is based on vehicle speed and traffic density. However, since evaluating LoS is subjective, a relationship between average speed and speed limits is suggested. It compares the average vehicle speed against the local speed limit (avg. speed/speed limit). Values closer to zero indicate the worst traffic flow and the closer to one being the best. Aiming to evaluate this metric, it can be used the same procedure used for evaluating the city's physical infrastructure. This technique implies the use of Web Map Services within a large sample of randomly selected locations.

For the evaluation of the driving patterns that drivers follow in the region of interest, several authors use a set of Characteristic Parameters (CPs) [52]. They are metrics based on the speed versus time profiles that drivers follow, such as average speed, average positive acceleration, idling percentage, and any other derivation from them. Some other authors use speed versus time profiles (driving cycles) to describe driving patterns. The representative driving cycle can be obtained by instrumenting a large sample of vehicles to obtain at $1 \mathrm{~Hz}$ information about the fuel consumption, speed, and geo-localization, simultaneously. Then, the collected database of sampled trips is used to construct the representative driving cycle by the micro-trips, Markov, or trip-based method. Quirama et al. [52] describe in detail the methods of obtaining representative driving cycles. In addition, the frequency distribution of VSP (vehicle specific power) and the frequency distribution of speed and acceleration can be used for describing the driving the local pattern.

\subsection{Assessment}

After the key performance indicators $\left(K P I_{i}\right)$ are evaluated, in this third phase, they are compared against reference values $\left(K P I_{i}^{+}\right.$and $\left.K P I_{i}^{-}\right)$. They are the lowest and highest benchmarks values observed for the ith indicator in the cities with similar characteristics, respectively. Table 3 shows the values selected in this work for $K P I_{i}^{+}$and $K P I_{i}^{-}$. Additional work is required to confirm that these values are appropriate for the purpose of assessing sustainable urban mobility. 
Then, each $K P I_{i}$ is normalized according to Equation (2) or (3), depending on whether their variation has a positive or negative connotation. Equation (2) is used if the connotation is positive. In all cases, $S_{i}$ ranges between 0 and $100 \%$, where $100 \%$ is the best [18].

$$
\begin{gathered}
S_{i}=\frac{K P I_{i}-K P I_{i}^{-}}{K P I_{i}^{+}-K P I_{i}^{-}} \\
S_{i}=1-\frac{K P I_{i}-K P I_{i}^{-}}{K P I_{i}^{+}-K P I_{i}^{-}}
\end{gathered}
$$

Subsequently, an Urban Mobility Index (UMI) is quantified as the weighted average value of the $S_{i}$ through Equation (4), where $n$ is the total number of evaluated indicators, and $W_{i}$ is the weighting factor that reflects the relative importance of each $S_{i}$ in evaluating urban mobility. Since we did not have any reasonable criteria to assign the relative importance of each $K P I_{i}$, in this work, as a first approximation, all $S_{i}$ have the same relative relevance and, therefore $W_{i}=1$.

$$
U M I=\frac{\sum_{i=1}^{n} W_{i} S_{i}}{n}
$$

Finally, inspired by the concept of level of service (LoS) described previously, a classification system is proposed where six ranges are defined, from A to F, to facilitate the compression of the value obtained [18]. This rating and classification system is shown in Table 4.

Table 4. Interpretation of the Urban Mobility Index (UMI).

\begin{tabular}{ccc}
\hline Score & Classification & Interpretation \\
\hline $80-100$ & A & Very high sustainable mobility \\
$60-79$ & B & High sustainable mobility \\
$40-59$ & C & Medium sustainable mobility \\
$20-39$ & D & Low sustainable mobility \\
$10-19$ & E & Very low sustainable mobility \\
$0-9$ & F & Unsustainable mobility \\
\hline
\end{tabular}

\section{Results}

As a case study of application, this section presents the results obtained implementing the methodology described in for the case of the City of Saltillo. It includes a detailed description of how the relevant information was obtained.

\subsection{Region of Study}

The city of Saltillo is the capital of Coahuila de Zaragoza, which is one of the Mexican states located northeast Mexico (Figure 2). Saltillo is at an average altitude of 1592 m.a.s.1. and exhibits a hot semi-arid climate (BSh, Köppen classification) with well-defined four seasons. Saltillo is mostly a flat region surrounded by mountain chains running from north to south on both sides. The average temperature of Saltillo is $18.3^{\circ} \mathrm{C}$, with an average temperature of $23.2^{\circ} \mathrm{C}$ in summer and $12.1^{\circ} \mathrm{C}$ in winter. Saltillo by itself covers up a surface of $272 \mathrm{~km}^{2}$ where the urban area corresponds to $240 \mathrm{~km}^{2}$ with a population of over 864,082 inhabitants (census year 2018), which results in an urban population density of around $3600 \mathrm{Hab} / \mathrm{km}^{2}$. Saltillo is considered one of the most industrialized areas of the country, with one of the largest automotive clusters in Mexico. Known industries such as General Motors, Fiat Group, Chrysler, Freightliner, Daimler, and Delphi are established in the region. In 2019, Saltillo had an estimated gross domestic product (GDP) of 32,000 USD per capita while the Mexican avg. GDP was 21,107 USD per capita the same year [53]. This amount was reduced from the 2019 by around 5\% due to the COVID-19 economic crisis [54]. 

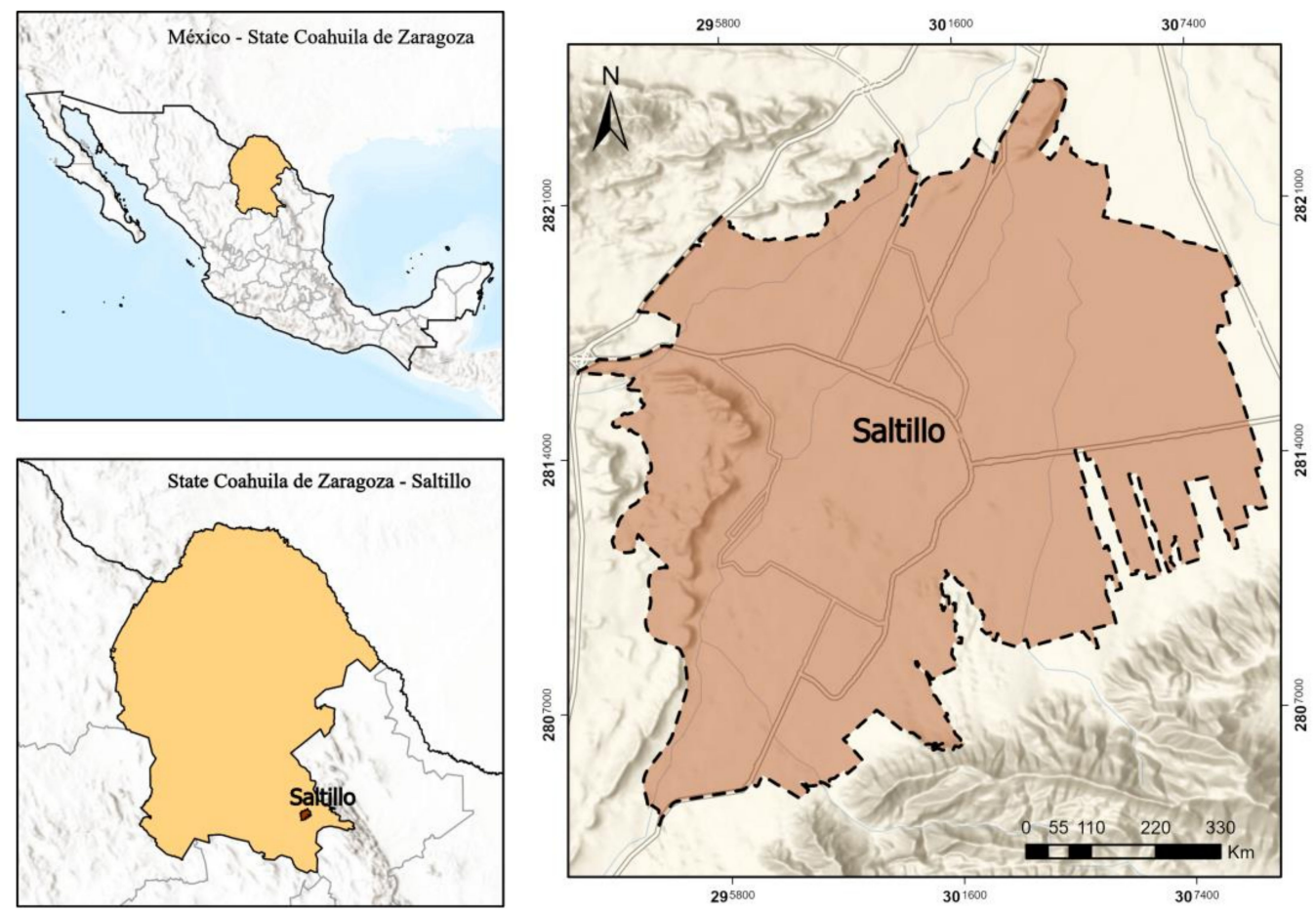

Figure 2. Location and topography of Saltillo. Source: Authors.

\subsection{Key Performance Indicators}

As described in the methodology section, in this phase, Saltillo's accessibility, government, environmental impact, and mobility will be described. The complete list of KPIs and the values obtained for Saltillo are detailed in Table 3.

\subsubsection{Accessibility}

Physical infrastructure: Based on public data, the Saltillo Metropolitan Area has $2987 \mathrm{~km}$ of roads-measured by the length of the central axis-and a road density of $411.9 \mathrm{~km} / 100,000$ habitants, of which $38.8 \%$ correspond to primary roads, $38.2 \%$ to secondary roads, and $23 \%$ to toll roads [55]. There are no exclusive lanes for public transportation. $68.5 \%$ of city blocks in Saltillo have paved roads. The greatest accessibility to sidewalks is concentrated in the interior of the city and in the areas with the highest housing density. The lowest levels of development of this type of infrastructure are distributed in the periphery of the municipality. In $55.2 \%$ of the city blocks, roads have pedestrian accessibility. In $29.9 \%$ of them, only some of their streets have pedestrian accessibility. In terms of pedestrian infrastructure for disabled people, only $2.6 \%$ of city blocks in Saltillo have wheelchair ramps on the roads. In terms of pedestrian streets and alleys, Saltillo is underdeveloped, with only $6.5 \mathrm{~km}$ throughout the city, representing $0.90 \mathrm{~km} / 100,000$ inhabitants [56].

Following the methodology based on Web Map Services stated in Section 2.2.1, a diagnosis of the mobility infrastructure of Saltillo was performed. The cartographic representation was obtained from the National Institute of Statistics and Geography [57]. It contains data from roads in Mexico. These data are then shaped into a GIS software (ArcMap) which consists of projecting and purifying all the road data contained. Then, a random geospatial sampling was carried out with the WMS software (Google Maps-Street View add-on). Fifty locations randomly distributed along the city's road network were considered to diagnose the roads. Data shown in WMS are based on public measurements between July 2009 and September 2019. Figure 3 shows an illustration of the steps followed on a single randomly selected location. 


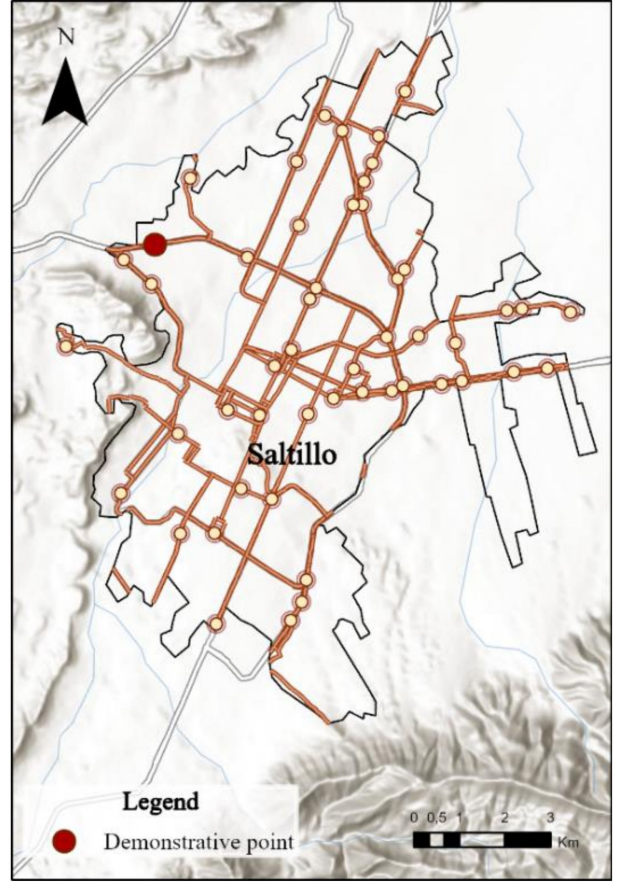

(a)

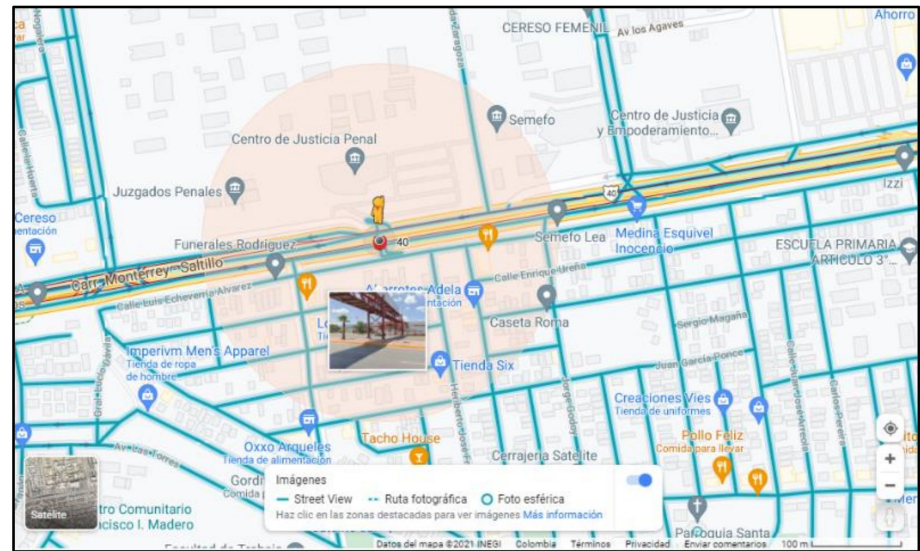

(b)

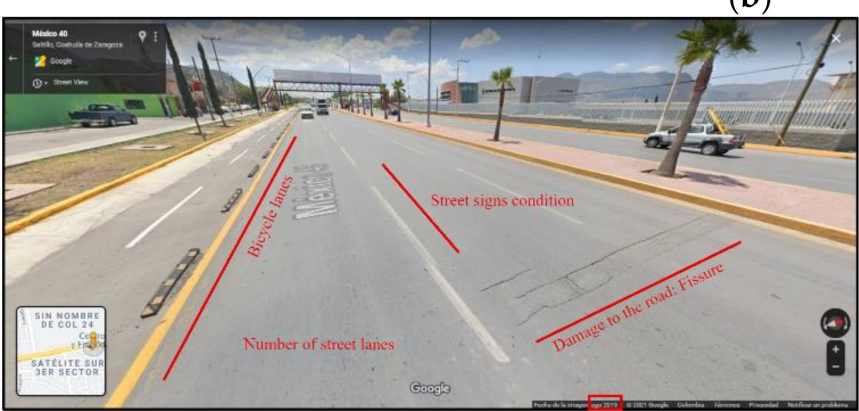

(c)

Figure 3. Illustration of using web map services to (a) sample, (b) locate, and (c) diagnose Saltillo's mobility infrastructure. Source: Authors.

Results obtained show that the infrastructure for mobility in the city of Saltillo has many opportunities for improvement. Of the points analyzed, the most frequent type of road is boulevards with $58 \%$, followed by streets with $20 \%$, while avenues and roadways exist in a lower proportion with $2 \%$. We used the classification established by the Mexican [57].

Asphalt coverage is the most common (98\%) in the roads analyzed, with mostly a favorable pavement condition. The remaining $2 \%$ are covered with stone (cobblestone). In relation to the damage observed on the roads, the losses of the layers of the structure cover $46 \%$, being reflected in flaking, potholes and/or patches in the asphalt surface layer, followed by cracks (37\%), and finally, deformations on the surface with $17 \%$. Sidewalks structures are present in $60 \%$ of the roads analyzed, street signs in $16 \%$, speed reducers in $12 \%$, and bike routes in $6 \%$. Results are summarized in Figure 4. 


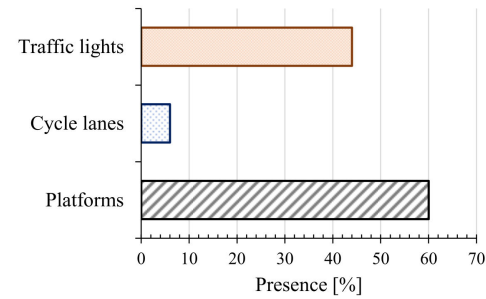

(a)

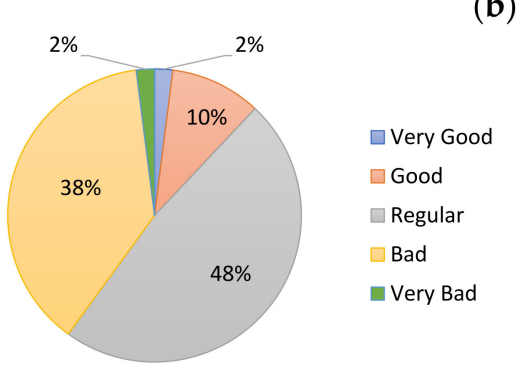

(c)

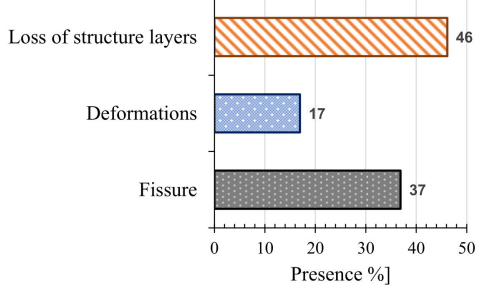

(b)

Figure 4. Saltillo roads (a) type, (b) deterioration, and (c) condition results using web map services.

Energy supply: Figure 5 shows the gas stations and e-charger currently operating in the city. It was obtained using web map services (google maps and Municipios de Mexico). This figure shows that the city has 90 gas stations and 6 electric vehicle (EV) charging stations. The fuel stations are widely distributed in the city, while outside this area, most of the stations are located within main avenues. On the other hand, the EV-charging stations are only located in the northern city, which substantially limits its accessibility.

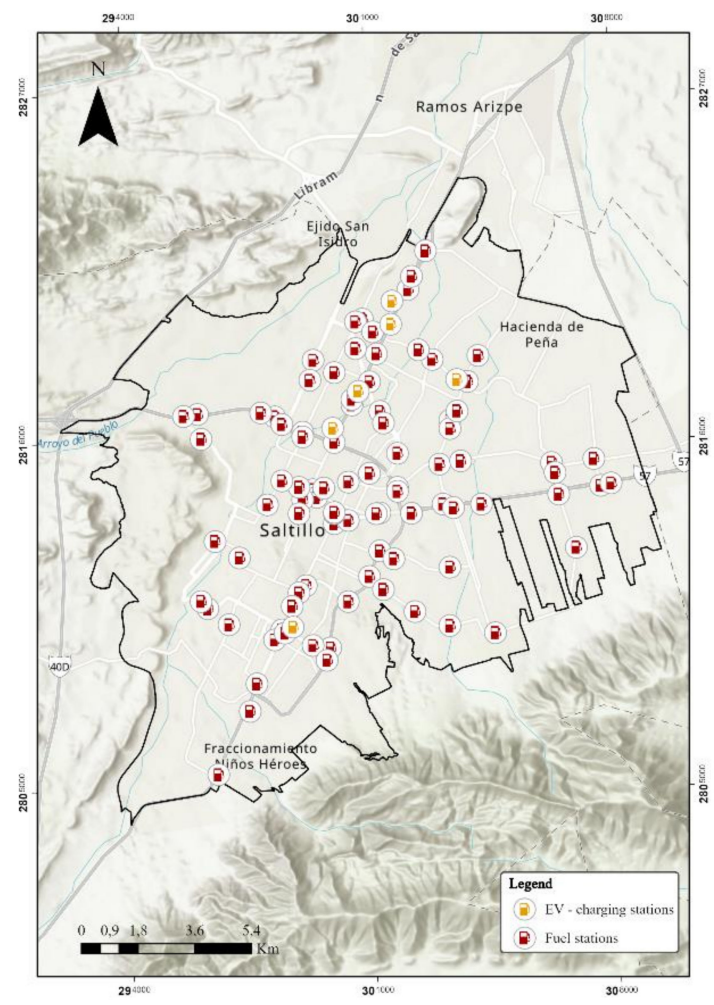

Figure 5. Location of gas stations and EV-charging stations in the city of Saltillo. Source: google maps (https:/ / www.google.com.mx/maps, accessed on 19 June 2021) and Municipios de México (https: / / www.los-municipios.mx/ precios-gasolina-saltillo.html, accessed on 19 June 2021). 
Vehicles for the Mobility of People and Goods: For Saltillo, both the database of registered vehicles in the area and an additional 2019 RSD monitoring campaign were considered for the fleet composition analysis. The database of registered vehicles in the area was obtained through the Secretariat of Communications and Transportation (SCT). This database was updated until 2020 with approximately 308,700 vehicles which represent approximately 0.31 vehicles per capita. This database details the vehicle origin (municipality where it was registered), service (public, private, and official), fuel type, model year, vehicle line, and sub-line. An analysis of the database of the vehicles registered in Saltillo shows median age of $\sim 15$ years for all vehicles. The fleet is composed mainly of +10 -year-old vehicles $(67 \%)$, which implies a higher presence of technologically obsolete vehicles with very high mileage. The entire registered vehicle fleet is almost entirely composed of gasoline vehicles (99\%), with almost no presence of diesel, GNC, LGP, and hybrid/electric vehicles. Additionally, more than $99 \%$ of the vehicles registered in the city are of private properties, with less than $1 \%$ of public, federal, and state vehicles. Public transport in Saltillo is covered by 894 buses, which results in around 345 buses per private vehicle.

However, the composition of circulating vehicles obtained with the RSD campaign has more relevance in terms of mobility because it sampled the actual vehicles running in the city. The RSD campaign was carried out by the Mexican National Institute of Ecology and Climate Change (INECC) in 2019 between 26 and 30 August measuring 19,003 vehicles in five different locations of the Metropolitan Area of Saltillo using a FEAT RSD4600. Finally, 12,233 valid records were obtained in this study after considering only platematched vehicles within the device thresholds. Details of the campaign can be found in reference [58]. When considering only the circulating vehicles through the RSD campaign previously mentioned, it was found, as expected, that newer vehicles tend to have higher vehicular activity (Figure 6a). The median age of circulating vehicles reduces substantially from 8.1 to 6 years old. Figure $6 \mathrm{~b}, \mathrm{c}$ show the characteristics of the vehicles that circulate in Saltillo in terms of vehicle line, and sub-line. It is observed that close to $45 \%$ of the market is covered by two vehicle brands, while almost $10 \%$ of the vehicles correspond to one vehicle sub-line (Nissan Sentra, locally known as Tsuru). This latter observation is of great importance because this vehicle model is still widely used as a taxicab in Mexico. It is based on outdated technology that was commercialized between 1990 and 1993 in the US, while in Mexico, it was still widely sold as brand new until 2017 with almost no changes. This difference in model-year technologies has a major impact on emissions. The motorization rate in Saltillo in 2014 was 314 vehicles/1000 habitants. In the last 15 years, the vehicle fleet increased by 150,000 cars. Car purchases are concentrated in higher-income segments. However, due to factors such as easy access to credit and the long-life cycle of vehicles, car purchases in low-income sectors have increased [59].

For cargo and goods transportation, the Saltillo Metropolitan Area also uses two railway lines, Kansas City Southern and Ferromex, which ease the mobility of cargo from the industrial zone of Saltillo and Ramos Arizpe. Arteaga is not connected to the railway system, but its proximity allows it to use its service when necessary [59].

City distribution: Saltillo is a dispersed urban center due to the existence of several void urbanized land set aside by speculators, who, waiting for a price increase, leave them idle for several years until they can be considered a profitable investment. This fact forces new urban developments to take place further away from the city center.

The city is characterized by concentrating the greatest tourist attraction in its Historic Center and in its industrial zone. The most important services and economic activities of the municipality are found in these areas (Figure $7 a, b)$. The main areas of origin of the trips are within the perimeter of the center of the municipality, where the areas with the highest housing density are concentrated (IMPLAN, 2016a). Additionally, as seen in Figure 7c,d, the city's pedestrian infrastructure is reduced within the perimeter of the municipality. Saltillo is one of the industrial poles of northern Mexico and one of the fastest-growing economic poles in recent decades. In this sense, its dynamic economic activity has driven the expansion of its transport infrastructure. 


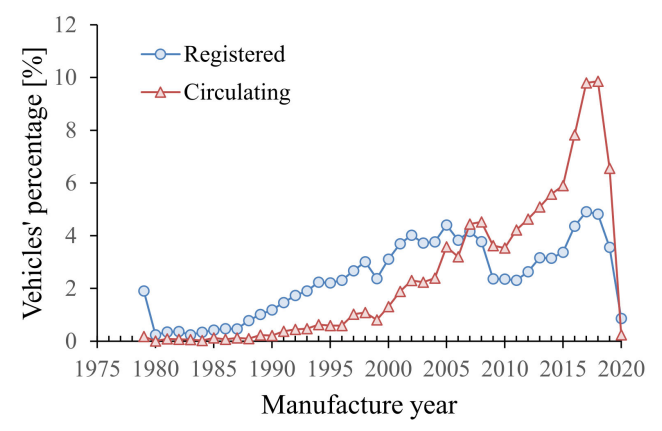

(a)

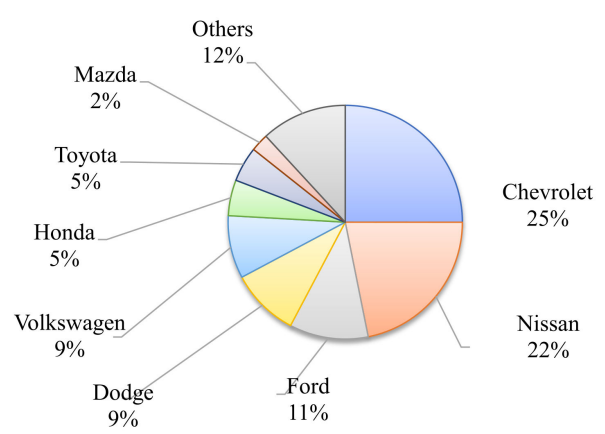

(b)

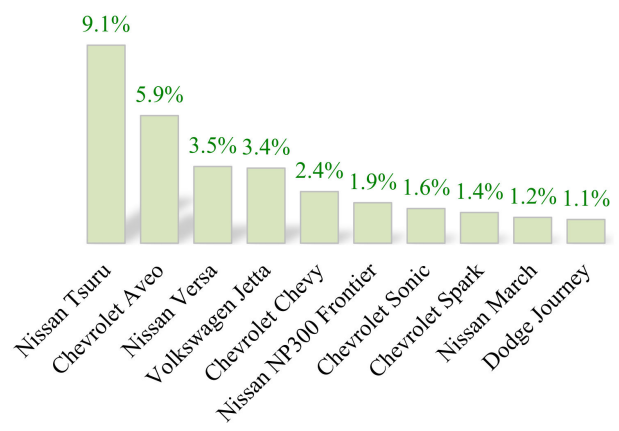

(c)

Figure 6. Fleet characteristics of the vehicles in Saltillo in terms of vehicle (a) age, (b) line, and (c) sub-line.

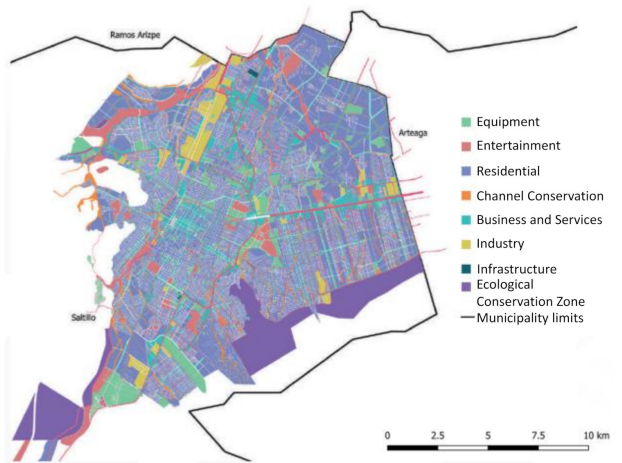

(a)

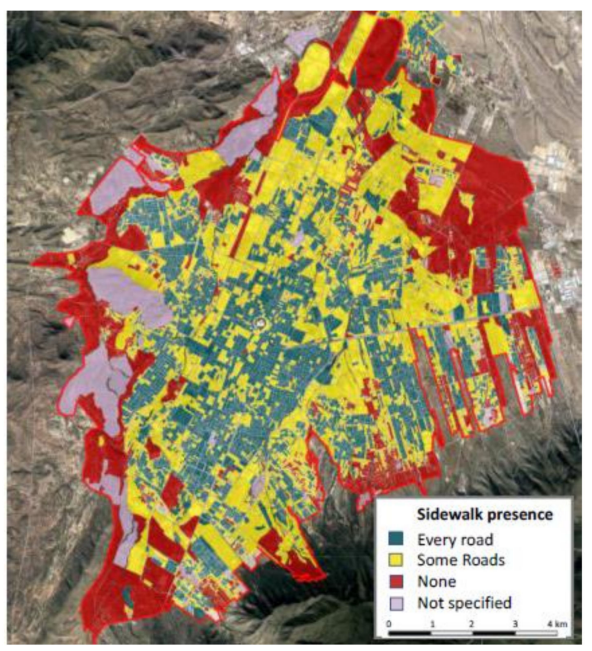

(c)

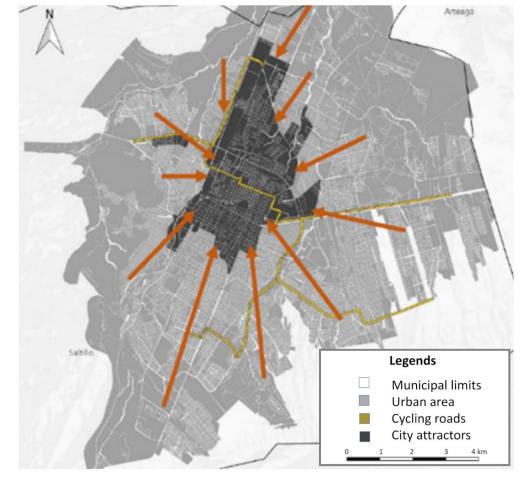

(b)

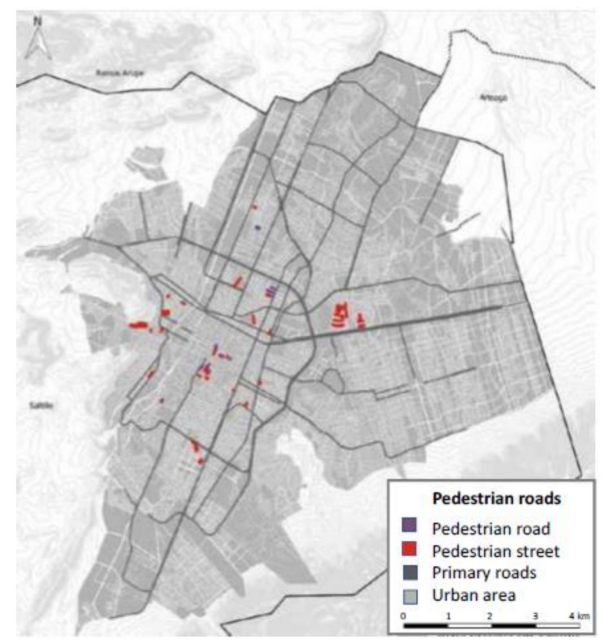

(d)

Figure 7. Saltillo's urban distribution in terms of (a) infrastructure, (b) attraction centers, (c) access to pedestrian infrastructure, and (d) pedestrian-only streets. Source: images adapted from $([55,60])$. 


\subsubsection{Government}

The authorities involved in the mobility system of Saltillo are detailed hierarchically in Figure 8. The Municipal Transportation Institute, a decentralized public organism, oversees the public transportation service in Saltillo. Its functions are to monitor, improve, plan, control, and regulate the operation, training, evaluation, and procurement of said service. This is complemented by the functions of the Municipal Planning Institute (IMPLAN), also a decentralized public organism, which has among its objectives to carry out studies and technical projects, in terms of mobility and public transport, to guarantee an efficient, economical, and clean service, in compliance with the existing regulations for the conservation of the environment. To promote citizen participation in the decision-making process, the Citizen Council for Coexistence and Sustainable Mobility of the Municipality of Saltillo was installed as an advisory support body where citizens participate in decision-making processes related to issues of sustainable mobility [55]. Five major promoters of non-motorized transportation and sustainable mobility have been identified in Saltillo.

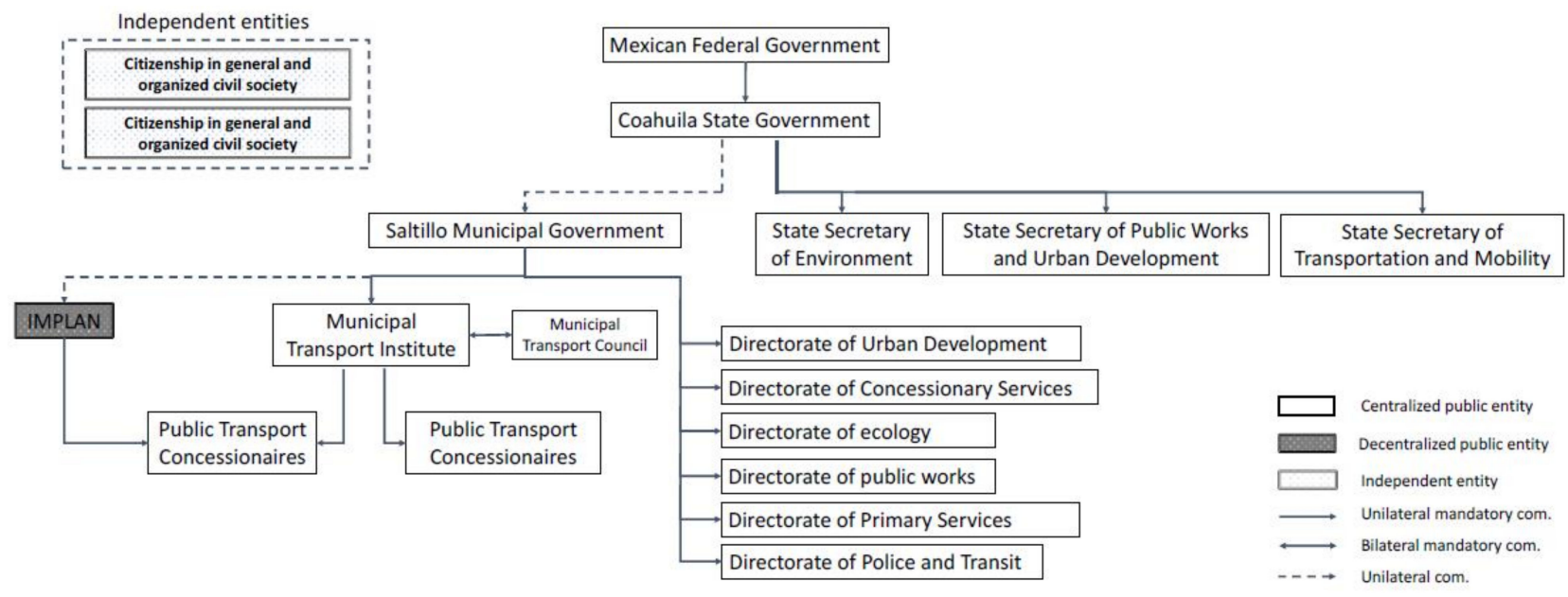

Figure 8. Saltillo's government organization related to urban mobility.

Comision de movilidad is a local public organization in charge of the city's mobility and transport.

Universidad Carolina is a private university that has been working on developing a California District that embraces surrounding neighborhoods into urban regeneration strategies, including mobility infrastructure improvements.

Ciclismo urbano de Saltillo and Rueda Limpio are two non-profit organizations that promote the bicycle as an alternative to vehicles and work continuously to obtain improvements on public cycling infrastructure.

Consejo Ciudadano de Convivencia y Movilidad Sustentable (CCCMS) is an entity that has been constituted from the city council. It is attended by the municipal president, enthusiasts, and experts in the field of mobility and has the participation of municipal institutions, which allows for legal and constant communication between citizens and the government.

Regulations: In the Political Constitution of the State of Coahuila de Zaragoza, the "right to free mobility" is not mentioned, nor in the Traffic and Sustainable Mobility Law. The municipal administration regulations establish that they are responsible for the formulation and application of programs for the public transport of passengers and its regulations, as well as the necessary measures for the protection of human life and the environment [61]. As a result, the Municipality of Saltillo has established the following regulations:

1. Law of Transit and Transport of the State of Coahuila de Zaragoza (1996): This law regulates transport services as well as the conditions of concessions. It addresses different 
aspects of the transport operation, such as authorized schedules, frequencies, routes, and years of operation of public vehicles [62].

2. Law for the Development and Inclusion of Persons with Disabilities in the State of Coahuila de Zaragoza (2013): This law establishes that the General Department of Urban Management, Water, and Planning and the General Department of Infrastructure oversees the designing, establishing, and monitoring compliance with regulations focused on the mobility of persons with disabilities in the city [63].

3. Saltillo Urban Development Master Plan (2014): This strategic plan sets out the main objectives in terms of mobility, transport, and guidelines for the construction of roads and parking infrastructure in Saltillo. In terms of mobility and transport, it seeks to solve conflict points in the city's road network, improves connectivity with the Derramadero area (an important commercial town located $32.7 \mathrm{~km}$ southwest of Saltillo), and creates alternative road options in the east of the municipality. It also aims to improve the average speed of public transport journeys to levels similar to those of private vehicles and aims to develop specific roads for freight transport and alternative mobility. It also seeks to discourage the entry of private cars into strategic areas of the city to benefit the operation of public transport [64].

4. Traffic and Transport Regulation for Saltillo (2015): This regulation establishes the rules concerning public transport and defines the local authorities in charge of monitoring the compliance of said regulation. In accordance with these provisions, the municipality is responsible for establishing the rules regarding timetables, fares, and rules for the use of public transport vehicles. In addition, the municipality supervises the locations of bus stops and terminals in the city, as well as the routes and frequency of public transport [65].

5. General Law on Human Settlements, Territorial Planning and Urban Development (2016): This law establishes ensuring the interconnection of roads and shared-use paths with human-scale design as a responsibility of the government. It also promotes the adoption of new urban mobility and accident prevention habits to improve people's travel conditions by encouraging the intensive use of public and non-motorized transport. In addition, it encourages the provision and preservation of spaces for pedestrian and bicycle traffic and connectivity criteria between roads that promote urban mobility [65].

6. Sustainable Mobility Law of the State of Coahuila de Zaragoza (2017): This law establishes the general conditions for the operation of infrastructure for persons with disabilities, pedestrians, and users of public transport and non-motorized vehicles. It promotes public policies aimed at shifting the use of private vehicles to public transport as well as establishes the plan for the adoption and replacement of public transport vehicles and promoting the implementation of subsidies, loans, and provisions to achieve this objective [66].

Out of these regulations, Saltillo has established the following strategies related to urban mobility:

Mobility strategies implemented: The city of Saltillo was born from a historic center of a few blocks. At first, the urban area built was of a size that allowed its inhabitants to make their tours on foot without much effort. However, like many Mexican cities, Saltillo has been the victim of uncontrolled urban expansion since the 70s. Consequently, from the early nineties to 2010 , the population grew $64 \%$, while the urban area increased by $268 \%$ in a similar period [64]. This fact caused the private automobile to become the most efficient mode of transport in the city and to monopolize a large part of public and private resources, in such a way that, in the first decade of this century, one of the largest road investments was made in the construction of bridges and overpasses that cross the city from north to south and from east to west to solve the growth of the vehicle fleet and the traffic caused by them. At the same time, the first bicycle lanes in the city were developed, and the weekend cycle ride and the first public bicycle system for Saltillo were launched. In addition, the restructuring of the public transport service called Saltibus was established. Currently, the 
city continues to grow with a car-oriented design, and the investment in sustainable modes of transport has been limited. As a result, the gap between the two in the dispute (public vs. private) for public space has increased.

Expansion and strengthening of cycling infrastructure: In recent years, the city of Saltillo has developed different initiatives to strengthen cycling infrastructure, consolidating a network of bicycle lanes. It is expected to increase the number of bicycle trips in the city's modal share to $7 \%$. To this end, different interventions have been designed as part of the strategic road plan proposed by the Saltillo Urban Development Master Plan, which seeks to redistribute public space in an efficient and functional way [59].

Public transport restructuring: The municipal administration has focused on the creation of a comprehensive transport system, reorganizing its routes, and carrying out a regulatory reform in this area. The "Strategic Plan for Corridors and Auxiliary Routes" is considered the starting point of this initiative and was presented in 2016. IMPLAN elaborated a proposal for the organization of routes. Toward this end, a model was proposed that can be implemented in several phases, in which there are trunk routes that are configured as corridors and feeder routes that are structured as auxiliary routes. The corridors will cover the areas of greatest demand, and the auxiliary routes will cover the more residential areas. As the first phase of this project, it is planned to start with the public transport network in the western part of the city [59]. In addition, strategies to develop this project include the following:

- Development of exclusive bus lanes.

- Optimization of the existing bus lane network,

- Incorporation of express buses Saltillo-Ramos Arizpe and Saltillo-Arteaga.

- $\quad$ Building efficient transfer stations. - Integrating fares and ticketing.

- Generating complete and accurate information for users.

Transport interventions in the consolidation of Saltillo's Historical Center: The municipal government of Saltillo has among its strategic urban projects the recovery of its Historical Center, which currently has very deteriorated areas in terms of housing infrastructure, commerce, public spaces, and transport. It seeks to develop a Transport-Oriented Development Model, which incorporates proposals for inclusive, equitable, and sustainable mobility. It also proposes the need to invest in the construction of large-scale transport infrastructure, consolidating and expanding the municipality's integrated transport network [67]. The historic center of the city is an area where there is a great deal of pedestrian activity. In recent times, different roads in the Historical Center have been intervened, but despite the large number of people who walk daily through this area, the infrastructure conditions are far from ideal for comfortable, accessible, and safe movement in most of the roads [67]. According to IMPLAN studies, two alternatives are identified to reduce the negative impacts of the "oversupply" of public transport: (i) creating exclusive roads for public transport or (ii) redistributing existing buses and routes in a balanced way. Neither of these alternatives addresses the causes of the problems in the public transport service, but only displaces them by moving them to other parts of the city center. Additionally, there are streets that could be used as exclusive for public transport and where urban regeneration in favor of public transport, cycling, and pedestrian mobility could take place [68]. Cycling infrastructure within the historic center of Saltillo is practically non-existent. There are no confined cycle lanes or priority cycling lanes. Therefore, cyclists must ride on the road or on the sidewalks. Moreover, there are no on-street bicycle parking facilities, and only three public bicycle loan stations are in place. Table 5 lists (chronologically) the major mobility strategies carried out in Saltillo. 
Table 5. Timeline of the mobility strategies implemented in Saltillo.

\begin{tabular}{|c|c|c|}
\hline Year & Strategy & Reference \\
\hline 2004 & $\begin{array}{c}\text { Improved buses, cards, created routes, surveyed } \\
\text { origin-destination. }\end{array}$ & \\
\hline 2013 & IMPLAN establishment & $\begin{array}{l}\text { http:/ / www. } \\
\text { implansaltillo.mx/, } \\
\text { accessed on } 31 \text { July } 2021\end{array}$ \\
\hline 2015 & East Area Public Transport Analysis-Boulevard Carranza & \\
\hline 2015 & Urban mobility indicator system & [56] \\
\hline 2015 & $\begin{array}{l}\text { Recommendations guide for the improvement of the bike } \\
\text { path segment: Government Center-Distributor Vial "El } \\
\text { Sarape" }\end{array}$ & [69] \\
\hline 2015 & $\begin{array}{l}\text { Recommendations to the project denominated: "update } \\
\text { technology of parking meters }\end{array}$ & [70] \\
\hline 2016 & Analysis of urban mobility in the Saltillo historical center & [68] \\
\hline 2017 & Design guide for pedestrian infrastructure. & [71] \\
\hline 2019 & $\begin{array}{c}\text { Study of vehicular emissions in the city of Saltillo using } \\
\text { the remote sensing technique }\end{array}$ & [58] \\
\hline 2020 & Proposal for reorganizing mobility in the historic center & \\
\hline
\end{tabular}

\subsubsection{Environmental Impact}

Vehicle Energy consumption: For the case study, measurements through the On-Board Diagnostic (OBD) port and a Global Positioning System (GPS) were carried out on 14 vehicles for 16 months between February of 2019 and June of 2020, obtaining a total of 2.09 million of records. For data quality analysis, trips with more than $5 \%$ of missing data were neglected.

In our test vehicles, the volumetric fuel consumption rate $\left(\dot{V}_{f}\right)$, expressed in $\mathrm{L} / \mathrm{s}$, was reported by the Engine Control Unit (ECU) through the OBD port. It was estimated through Equation (5). It uses data from the mass airflow sensor $(M A F)$, the corresponding fuel stoichiometric air-fuel ratio (AFR), and the region of study declared fuel density $(\gamma)$, which is $870 \mathrm{~g} / \mathrm{L}$ for Saltillo [72]. This technique has been previously validated with an error lower than $6 \%[73]$.

$$
\dot{V}_{f}=\frac{M A F}{A F R \cdot \gamma}
$$

Figure 9 details the Specific Fuel Consumption (SFC) obtained of each vehicle category measured, expressed as quartiles. The horizontal line marks the median value, while the whiskers indicate variability outside the upper and lower quartiles. When considering the fuel consumption of cargo freight, the best way to analyze trucking efficiency is to determine the SFC per ton of freight weight $\left(S F C^{*}\right)$ [74]. Therefore, to include the cargo freight category into the analysis, this metric is used for every category measured. Figure 9 shows that cargo vehicles are the most energy-efficient.

Vehicles' emissions: Aiming to evaluate Saltillo's vehicle emissions, the latest local anthropogenic emissions inventory was retrieved from the Secretariat of Environment and Natural Resources [75]. The methodology used in the emissions inventory in Saltillo is detailed within the guide for the preparation and use of emissions inventories prepared by the Mexican's National Institute of Ecology and Secretary of the Environment and Natural Resources, in collaboration with the Western Governors Association [76]. In Saltillo, the vehicles are the primary source of $\mathrm{CO}$, the secondary source of VOCs and PM, and the tertiary source of NOx (Table 6). 


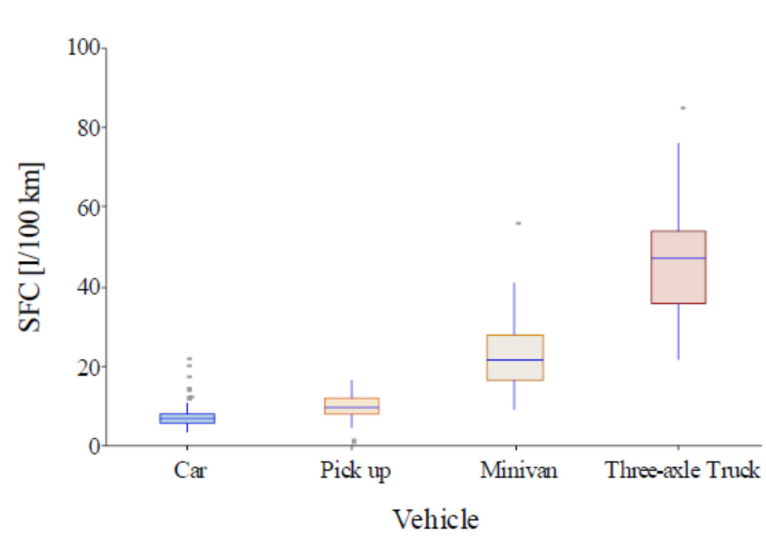

(a)

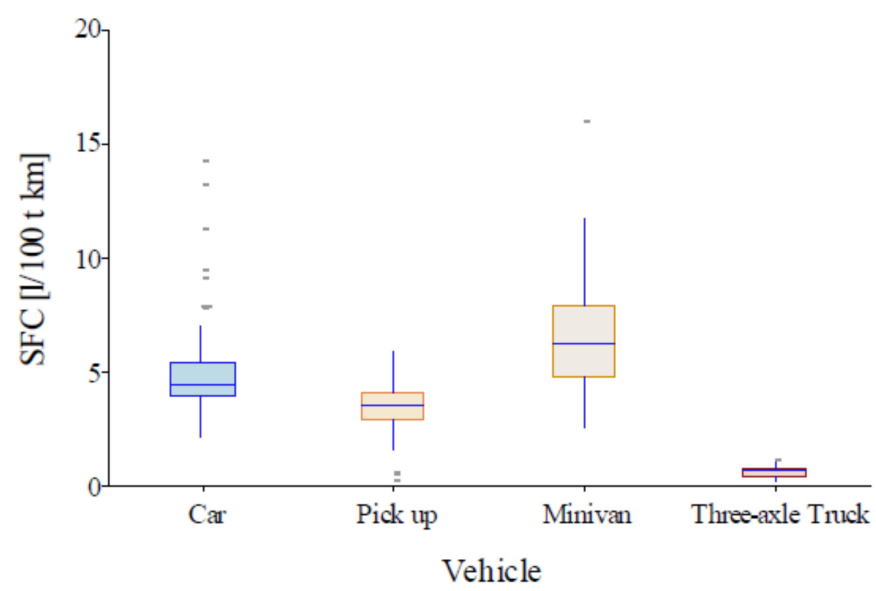

(b)

Figure 9. Saltillo's fuel consumption of different vehicle categories expressed as (a) SFC and (b) SFC* (SFC per ton transported).

Table 6. Emissions inventory of Coahuila State 2014. Source: Table taken from [75].

\begin{tabular}{|c|c|c|c|}
\hline & Primary Source & Secondary Source & Tertiary Source \\
\hline $\begin{array}{c}\text { Volatile Organic Compounds } \\
\text { (VOCs) }\end{array}$ & Automotive industry (30\%) & $\begin{array}{c}\text { SUV and Pick-up vehicles } \\
(17 \%)\end{array}$ & $\begin{array}{l}\text { Passenger vehicles and } \\
\text { taxicabs }(29 \%)\end{array}$ \\
\hline Carbon Monoxide (CO) & $\begin{array}{l}\text { SUV and Pick-up vehicles } \\
(39 \%)\end{array}$ & $\begin{array}{l}\text { Passenger vehicles and } \\
\text { taxicabs }(29 \%)\end{array}$ & Vehicles under 3 tons ( $9 \%$ ) \\
\hline Nitrogen Oxides $\left(\mathrm{NO}_{\mathrm{X}}\right)$ & Generation of electricity ( $43 \%)$ & Metallurgical ind & $\begin{array}{l}\text { Vehicles under } 3 \text { tons and } \\
\text { tractor units }(11 \%)\end{array}$ \\
\hline $\begin{array}{c}\text { Particulate Matter smaller than } \\
10 \text { micrometers }\left(P_{10}\right)\end{array}$ & Metallurgical industry (43\%) & Unpaved roads $(20 \%)$ & Generation of electricity $(7 \%)$ \\
\hline $\begin{array}{l}\text { Particulate Matter smaller than } \\
2.5 \text { micrometers }\left(P M_{2.5}\right)\end{array}$ & Metallurgical industry (59\%) & Unpaved roads $(8 \%)$ & Generation of electricity $(6 \%)$ \\
\hline
\end{tabular}

In addition, the results from the 2019 RSD monitoring campaign for on-road emissions were also included in this analysis. This RSD monitoring campaign was previously described in Section 3.2.1. Aiming to avoid atypical data, as suggested by Mexican RSD standards, only results from vehicles driven under vehicle speeds between 1 and $35 \mathrm{mph}$ $(\sim 1.6$ to $55 \mathrm{~km} / \mathrm{h})$, positive accelerations between -2.8 and $4 \mathrm{mph} / \mathrm{s}\left(\sim-1.2\right.$ and $\left.1.8 \mathrm{~m} / \mathrm{s}^{2}\right)$, and with $V S P$ values between 3 and $20 \mathrm{~kW} /$ metric-Ton were considered [48]. VSP is the power demanded by the engine. VSP, expressed in $\mathrm{kW} /$ Metric Ton, was obtained with Equation (6) using typical values [77]. In this equation $v$ and $v_{w}$ are the vehicle speed and wind speed respectively, both expressed in $\mathrm{m} / \mathrm{s}, m$ is the road grade expressed as a percentage, and $a$ is vehicle acceleration in $\mathrm{m} / \mathrm{s}^{2}$.

$$
V S P=v\left(1.1 a+9.81 m+0.132+3.02 \times 10^{-4}\left(v+v_{w}\right)^{2}\right)
$$

Table 7 shows the RSD campaign details and results obtained. It is important to highlight that the emission concentrations obtained by RSD do not reflect the real vehicle emissions in the study region since, in this test, vehicles are forced to moderate their speed when crossing the sampling locations. Nevertheless, the on-road emissions obtained through the RSD campaign allow the inclusion of the impact of the local conditions, the discretization of emissions per model-year, the identification of gross-polluters, emissions regulations compliance, and follow-up of the impact of new vehicle technologies introduced throughout the years. 
Table 7. Results of the Remote Sensing campaign carried out in Saltillo in 2019.

\begin{tabular}{|c|c|}
\hline & Saltillo \\
\hline \multicolumn{2}{|l|}{ Measuring site } \\
\hline Date & 26 to 30,2019 \\
\hline Campaign schedule & $08: 30$ to $16: 30$ \\
\hline \multicolumn{2}{|l|}{ Vehicles monitored } \\
\hline Total Measurements & 19,003 \\
\hline Valid measurements for $\mathrm{CO}, \mathrm{HC}$, and $\mathrm{NO}$ & 12,233 \\
\hline Licensed plate matched & 12,233 \\
\hline Adjusted to speed and Acceleration ranges* & 12,109 \\
\hline Adjusted to $V S P$ range & 11,477 \\
\hline \multicolumn{2}{|l|}{ Measurement conditions } \\
\hline Avg. Fleet age [years] & 8.1 \\
\hline Median Fleet age [years] & 6 \\
\hline Avg. Speed [mph] & 16.77 \\
\hline Median Speed [mph] & 16.31 \\
\hline Avg. Acceleration $[\mathrm{mph} / \mathrm{s}]$ & 1.11 \\
\hline Median Acceleration $[\mathrm{mph} / \mathrm{s}]$ & 1.05 \\
\hline Avg. VSP [kW/Ton] & 6.67 \\
\hline Median VSP [kW/Ton] & 6.29 \\
\hline Avg. Slope [Degrees] & 1.13 \\
\hline \multicolumn{2}{|l|}{ Emissions concentrations } \\
\hline Mean CO [vol \%] & $0.583 \pm 0.013^{*}\left(4.5^{* *}\right)$ \\
\hline Median CO [vol \%] & 0.118 \\
\hline Mean $\mathrm{HC}^{1}$ [ppm] & $398 \pm 11^{*}(600 * *)$ \\
\hline Median $\mathrm{HC}^{1}$ [ppm] & 47.5 \\
\hline Mean NO [ppm] & $595 \pm 10 *(2500 * *)$ \\
\hline Median NO [ppm] & 43.2 \\
\hline
\end{tabular}

${ }^{1} \mathrm{HC}$ expressed as propane equivalent; ${ }^{*}$ Standard error at 95\% confidence interval; ${ }^{* *}$ RSD emission limits established by national Mexican standard NOM-167-2017.

When considering the emissions concentrations by model-year found in Saltillo (Figure 10) a high correlation between age and deterioration was observed (usually linked to absences or deficiencies of periodical emissions controls). Additionally, Figure 10 shows a large presence of gross polluters that surpass the emissions thresholds established in Mexican RSD current regulations [48]. Further work is required oriented toward the evaluation of the percentage of vehicles not complying with emissions standards and estimating the impact of Inspection and Maintenance programs as a sustainable mobility strategy in this city, as detailed in Huertas et al. [51].

\subsubsection{Mobility}

Public transport in Saltillo is covered by 54 routes operated by 894 buses, which travel an average of $238,000 \mathrm{~km}$ daily (Figure 11a). Most routes converge in the city center, generating problems of traffic in the service provided, such as overlapping routes (in some cases, up to 20 routes cover the same road), low-speed levels (the average speed of the routes is $16 \mathrm{~km} / \mathrm{h}$ ), and deficiencies in the supply of transport in some areas of the city. The average journey time of public transport is $39.5 \mathrm{~min}$. $31 \%$ of trips last between 21 and $30 \mathrm{~min}$, followed by $19 \%$ of them lasting between 11 and $20 \mathrm{~min}$, and $13 \%$ lasting between 31 and $40 \mathrm{~min}$. It is estimated that most trips (34\%) are between four and seven kilometers [55]. Public transport is perceived as a very poor service with units in poor condition, inefficient routes, and not multimodal, so it is often seen as one of the last options for mobility. 


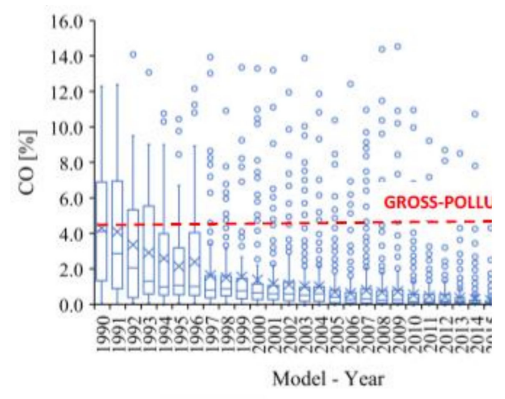

(a)

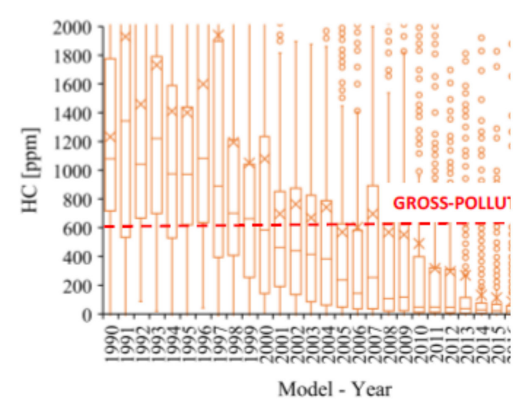

(b)

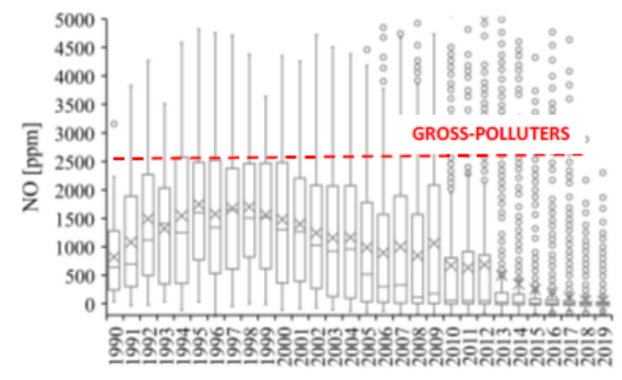

(c)

Figure 10. Saltillo model-year vehicle on-road (a) CO, (b) HC, and (c) HC emissions concentrations and regulations compliance.

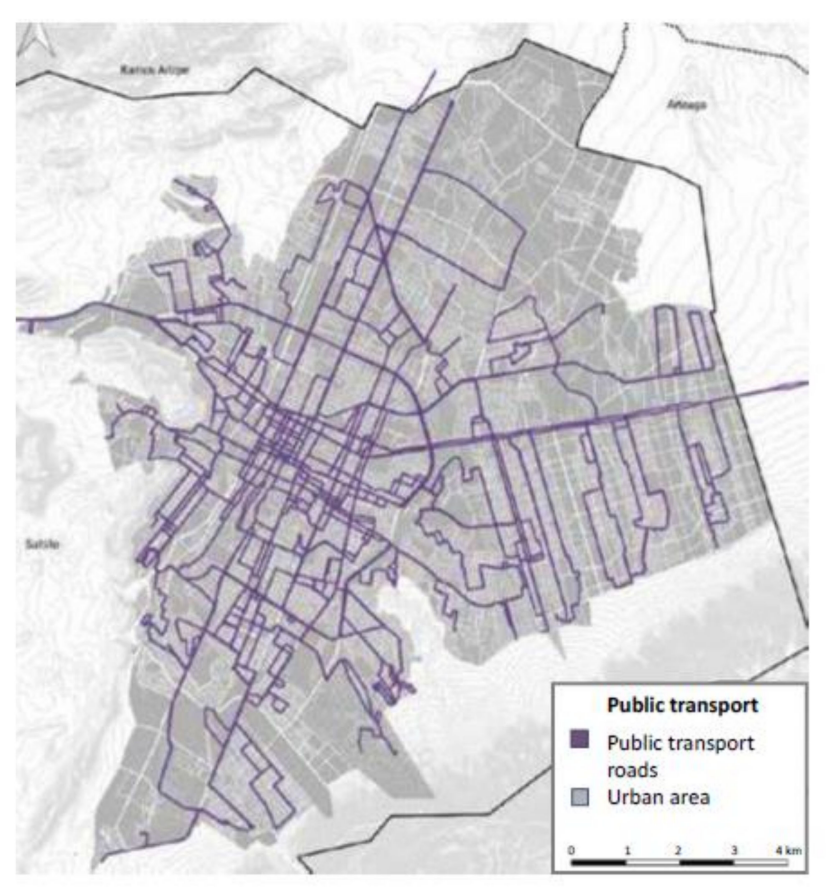

(a)

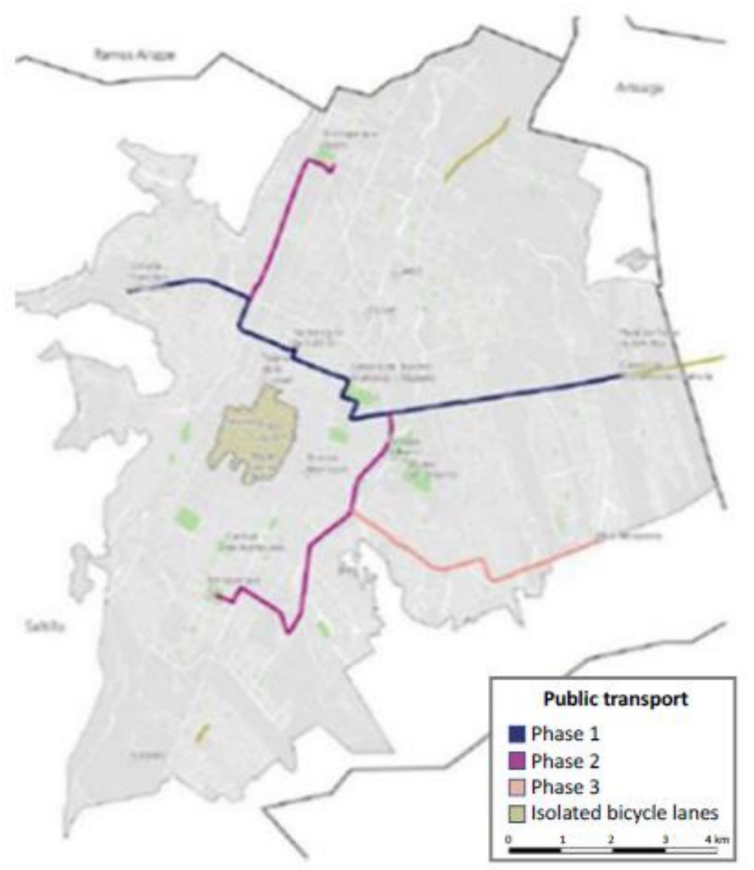

(b)

Figure 11. Road structure for (a) cars and (b) bikes in the Municipality of Saltillo. Source: Images adapted from [56].

In Saltillo, car use is still more efficient than public transport in terms of trip duration. The average travel time by car is $25.6 \mathrm{~min}$, while the average travel time by public transport is $39.52 \mathrm{~min}$ [56]. 
There is progress in considering cycling as an alternative mode of transport, but there is still great resistance due to the widespread belief in a large sector of society that the car reflects superior social status. The cycling infrastructure covers a considerable part of the city, but it requires maintenance. The bicycle road infrastructure in the Municipality of Saltillo is $34 \mathrm{~km}$ long (Figure 11b). Cycling is mainly used to travel to school and work, and trips are mainly made to the north and to the city center. Despite the unfavorable assessment of Saltillo's cycling infrastructure by its users, there is a willingness to switch from using cars or other means of transport to cycling if optimal street conditions exist in terms of infrastructure quality and safety. Bicycles represent less than $1 \%$ of the city's modal share. Bicycle users have been decreasing in recent years, showing a $60 \%$ reduction between 2014 and 2017. According to a survey conducted in 2018 in Saltillo, the main motivations of bicycle users to use this vehicle as a means of transport are health and leisure [36].

The city of Saltillo has an international airport called Plan de Guadalupe located in the municipality of Ramos Arizpe. In 2012 it registered an average of 60 flights per day, of which $70 \%$ were cargo flights operating around 8000 tons of cargo. The remaining $30 \%$ were passenger flights carrying 134,540 passengers [78].

Traffic congestion: The preference for private vehicles raises traffic congestions in Saltillo. As mentioned in the methodology section, a relationship between average speed and speed limits is suggested. It compares the average vehicle speed against the local speed limit (avg. speed/speed limit). Values closer to zero indicate the worst traffic flow and the closer to one hundred being the best. For this, the average speed of a sample of 50 randomly selected location were obtained through the Web Map Services and the telematics data mentioned in Section 2.2.4. The Saltillo average traffic flow ratio was 78\%, being the worst in the city's center $(22 \%)$. The values obtained in the randomly selected sample are shown in Figure 12.

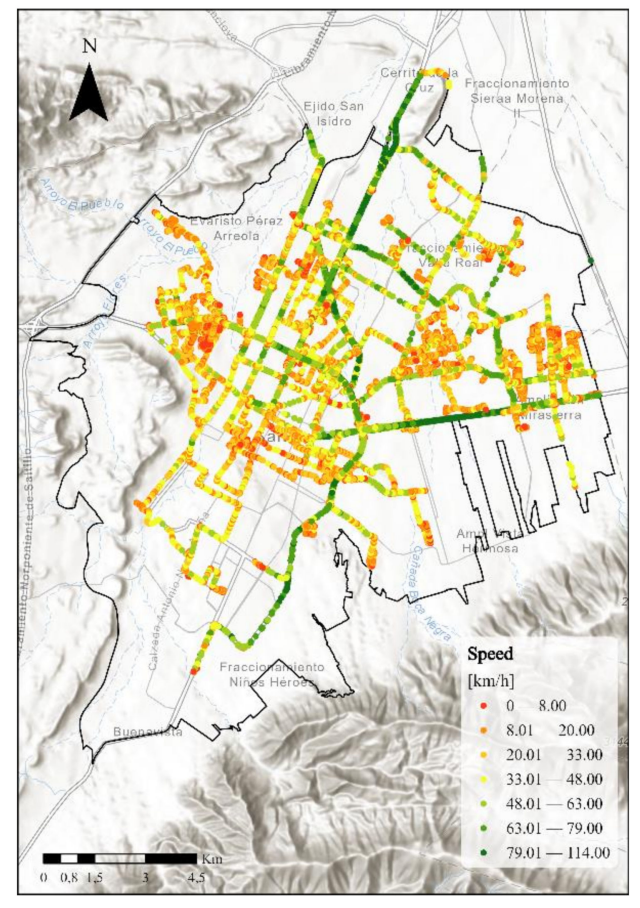

(a)

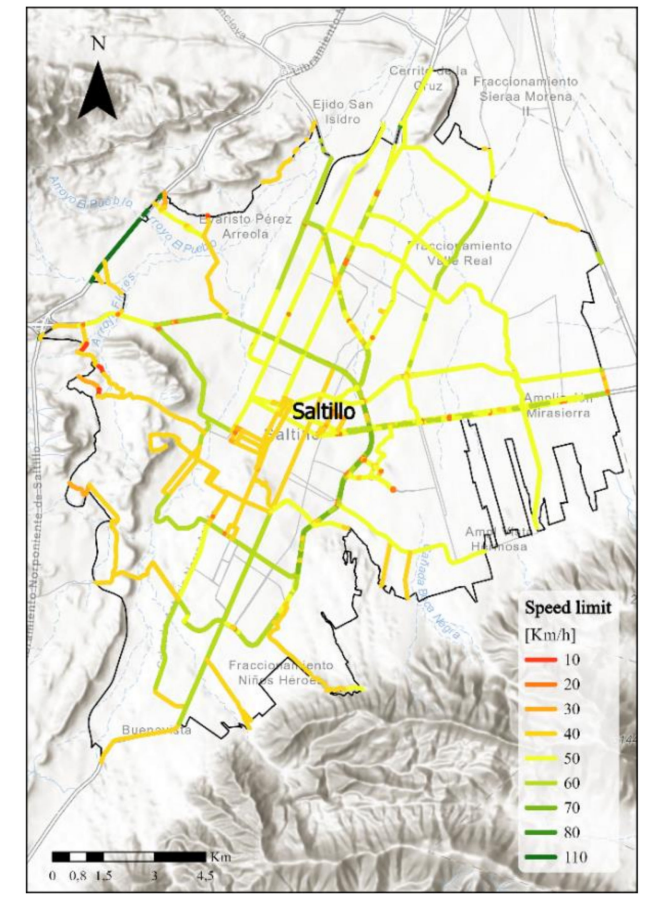

(b)

Figure 12. Saltillo's road traffic flow obtained by comparing the (a) vehicles' average speed against its respective (b) roads' speed limits using Web Map Services and telematics data.

Driving Patterns: Telematic data described in Section 3.2.3 were used to describe the Saltillo driving pattern following the procedures outlined in Section 2.2.4. A driving pattern describes the way people typically drive their cars. It is influenced by human factors (stress, cultural aspects, etc.) and external factors (traffic, road conditions, weather, 
etc.). Thus, it is the result or output of the mobility conditions within the city for the motorized mode of transportation. It has an implicit connection with energy efficiency and vehicular emissions. Figure 13 shows four alternatives to describe the typical driving pattern in Saltillo. Figure 13a shows the representative driving cycle of the city, Figure 13b the frequency distribution as a function of VSP and discretized by ranges of vehicle speed: low, $(<40 \mathrm{~km} / \mathrm{h})$, medium (between 40 and $80 \mathrm{~km} / \mathrm{h})$, and high $(>80 \mathrm{~km} / \mathrm{h})$. Figure $13 \mathrm{c}$ shows the frequency distribution as a function of vehicle speed and acceleration. Finally, Figure 13d shows the hourly vehicle speed during weekdays and weekends. Similar results have been observed in other LATAM cities [42,79]. Work is underway to grade mobility using as criteria the local driving pattern.

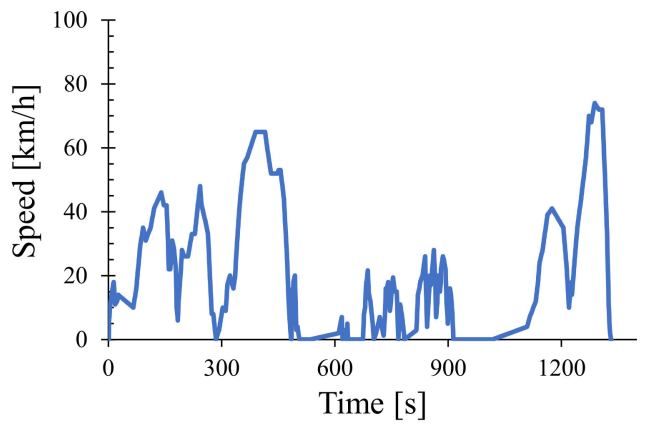

(a)

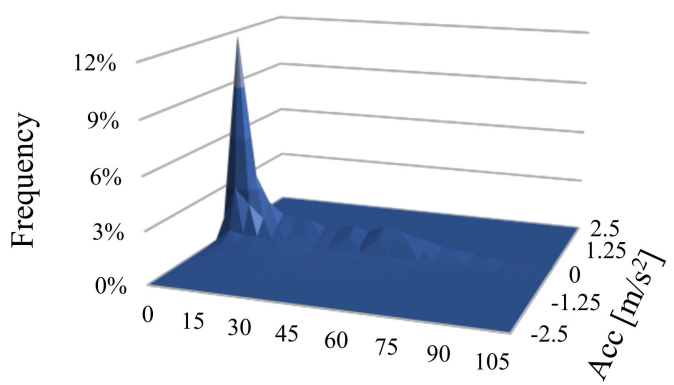

Speed $[\mathrm{km} / \mathrm{h}]$

(c)

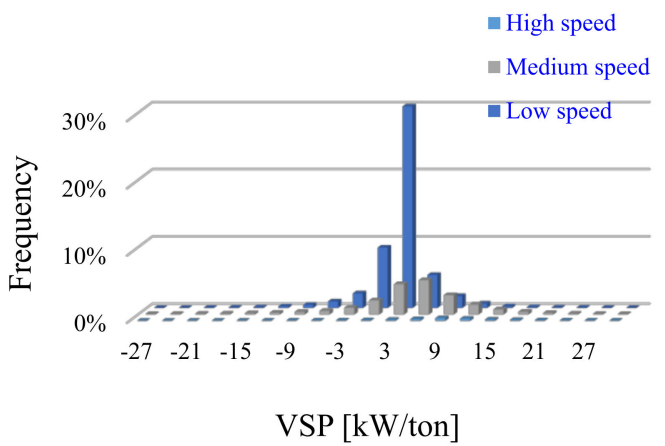

(b)

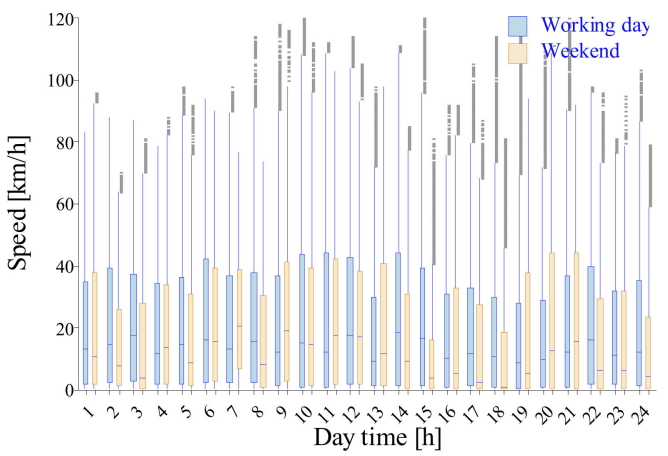

(d)

Figure 13. Description of the driving patterns through (a) driving cycle, (b) VSP frequency distribution by speed ranges, (c) Speed-Acceleration Frequency Diagram, and (d) hourly speed distribution for working days and weekend days, for the City of Saltillo as measured by using telematics.

\subsection{Assessment}

The values for each of the proposed $K P I_{i}$ were determined (Table 3 ), as well as their corresponding benchmarking values $\left(\mathrm{KPI}_{i}^{-}\right.$and $\left.\mathrm{KPI}_{i}{ }^{+}\right)$following the procedure outlined in Section 2.3.

The benchmarking values were established in different ways. Some values were taken from the Inter-American Development Bank (IDB) in its report Emerging and Sustainable Cities [80]. Other indicators were taken from the UITP [18]. The rest of the benchmark indicators were obtained from studies reported from cities with similar characteristics to Saltillo and from cities around the world that are known for having a good mobility system.

Benchmarks to evaluate environmental impact were taken from the results obtained from RSD campaigns carried out in Monterrey (MTY) and Los Angeles (LA) during 2018 and 2019. Details on these RSD monitoring campaigns can be found in Huertas et al. [50]. Monterrey was considered due to its similarities in fuel quality, fleet composition, and climate conditions. Los Angeles was included since it follows equivalent emissions stan- 
dards and because it is a referral city known for its high efforts on sustainable mobility and low emissions.

Subsequently, the $S_{i}$ were obtained by normalizing each $K P I_{i}$ through Equations (2) and (3), and finally, the UMIs were obtained through Equation (4) for each category considered (Table 8). Figure 14 shows the UMIs obtained for each category. It shows that according to Table 4, the city of Saltillo has a low level (level D) of sustainable mobility, and therefore it is urgent to implement aggressive strategies to improve its mobility system.

Table 8. Urban Mobility Index (UMI) per category for Saltillo.

\begin{tabular}{ccccc}
\hline Pillar & Category & UMI & Classification & Interpretation \\
\hline Accessibility & $\begin{array}{c}\text { Physical } \\
\text { infrastructure }\end{array}$ & 18.6 & $\mathrm{E}$ & Very low sustainable mobility \\
& $\begin{array}{c}\text { Economic scope } \\
\text { Energy Supply } \\
\text { Vehicles for the } \\
\text { mobility of people } \\
\text { and goods }\end{array}$ & 51.8 & $\mathrm{C}$ & $\begin{array}{c}\text { Medium sustainable mobility } \\
\text { Very low sustainable mobility }\end{array}$ \\
\hline City distribution & 43.3 & $\mathrm{E}$ & $\mathrm{D}$ & Low sustainable mobility \\
\hline Government & $\begin{array}{c}\text { Structure and } \\
\text { regulations }\end{array}$ & 100 & $\mathrm{C}$ & Medium sustainable mobility \\
\hline Impact & $\begin{array}{c}\text { Energy and } \\
\text { emissions }\end{array}$ & 27.4 & $\mathrm{D}$ & Low sustainable mobility \\
\hline Mobility & Mobility patterns & 44.1 & $\mathrm{C}$ & Medium sustainable mobility \\
\hline & Overall & 46.5 & $\mathrm{C}$ & Medium sustainable mobility \\
\hline
\end{tabular}

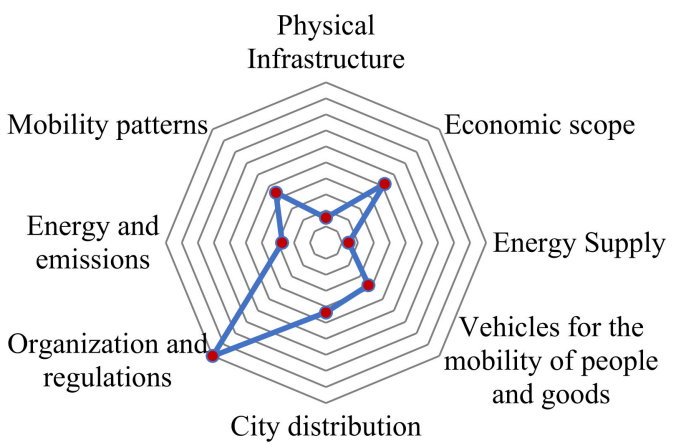

Figure 14. Assessment of the sustainable mobility in Saltillo.

\section{Discussion}

In the previous sections, a methodology to assess sustainable mobility was presented, and the results of implementing it for the case of Saltillo City were described. In the process of establishing and implementing the methodology, several key characteristics of the methodology were identified:

- The objective of the methodology is to assess the current situation of city mobility as a first step to identify the most effective sustainable strategies that the city should implement to improve the mobility of people and goods within the city.

- Sustainability is a key part of the methodology. Thus, the pillars aspects of sustainability (social, economic, and environmental) were included.

- In the process of defining the methodology, the special circumstances of LATAM cities related to urban mobility were taking into consideration. In most of these cities, people's mobility is based on buses. Cities are spread and located at high altitudes over mountainous regions. There is a marked social stratification with most of the people in the low-income segment. These low-income people usually live in the periphery of the city. These aspects influence the definition of the categories to consider and the reference values used for each $K P I_{i}$. 
- The methodology aims to ease the assessment process, at the lowest possible incremental cost, in a reproducible manner and producing results free from subjectivities. In this sense, the methodology is based on data. We propose the use of web map services, telematics data, results from the city's air quality monitoring network and from its inspection and maintenance program. All these data can be obtained at a reduced incremental cost. This essential characteristic of the proposed methodology will allow it to become a Monitoring and Reporting System (MRS) that continuously assesses the effects of the mobility strategies implemented in the city.

However, looking forward to a uniform, well-accepted, and eventually standardized methodology to access sustainable mobility in any city, several issues still need to be resolved:

Need for a reduced set of KPIs: there is a need to identify a reduced number of KPIs that truly capture the effects of the relevant categories on sustainable mobility. As its name indicate, each $K P I_{i}$ evaluates observable results (performance) related to the considered categories. In order to assess sustainability, the proposed pillars and categories should evaluate the economic, social, and environmental aspects related to mobility. Increasing the number of KPIs could mislead the conclusions of the assessment, dilute the relevance of the truly key indicators, and increase the difficulty and cost of carrying on the assessment. In this work, we kept the indicators most frequently used in the literature but only used a few of them as KPIs (Table 3).

Access to data: The KPIs should be evaluated through well-established procedures and based on data easy to obtain at a reduced incremental cost. The use of web map services to evaluate the infrastructure available in the city for mobility is easy to implement. Similarly happens with the use of telematics data to evaluate the average speed and real fuel consumption. In addition, most cities operate air quality monitoring networks and have implemented inspection and maintenance programs for their circulating vehicles. The proposed methodology use in its assessment of these data, which can be obtained at a relatively negligible incremental cost. However, access to this data and the permanent actualization of the data depends on third companies, and their analysis requires qualified personnel.

Need for reference values for each KPI $I_{i}$ free from subjectivities: the establishment of reference values for each $K P I_{i}$ is a major issue. People have a good sense of what sustainable urban mobility is. However, there is not a clear and well-accepted definition for it. As a consequence, it is hard to establish objective reference values. For example, the length of roads per habitant is a common KPI. Cities with few $\mathrm{km} / \mathrm{hab}$ of roads limit people's mobility and the transportation of goods. However, more $\mathrm{km} / \mathrm{hab}$ of roads do not imply better mobility. Highly concentrated cities do not solve their mobility problems by increasing the number of roads. Perhaps there exists an intermediate value for this $K P I_{i}$ that could be considered as a reference independently of the size of the city and its particularities. As a first approximation, in this work, we used as reference values for the $K P I_{i}$, the values reported for cities similar to Saltillo that people consider as having good mobility. Additional work is needed to identify the appropriate reference values for each $K P I_{i}$.

Inclusion of the smart mobility concept within the proposed methodology: Smart mobility is related to the use of data to reorganize the way people and goods move within the city. Therefore, this methodology must include additional KPIs and reference values to evaluate the degree of smartness of the urban mobility in the city under assessment.

Suitability of the methodology to identify strategies oriented toward improving sustainable mobility: The knowledge of the present situation of the mobility system thorough the methodology here proposed leads to identify the aspects of the mobility system that need to be improved. This is because the use of indicators per category connects observable effects related to mobility with its root causes.

However, this knowledge does not by itself identify the most effective sustainable strategies to be implemented. An additional intermediate step needs to be performed. Usually, authorities working in this area use common sense to fulfill this gap and explore 
the applicability of successful mobility strategies implemented in similar cities. We recommended the use of tools, such as MAITEC (Huertas-Cardozo, 2021), that evaluate the effect of the potential strategies on the city's mobility, energy consumption, air pollution, and impact on people's health, using micro traffic simulation plus the air pollutants dispersion modeling. However, the use of these tools is computationally expensive and required specialized personnel.

For the case of Saltillo, the mobility assessment and this additional step of exploring sustainable strategies to improve mobility resulted in the strategies listed below. They were conceived and ranked with the direct participation of the multiple stakeholders described in Figure. Details on the process of defining these strategies will be published in a companion paper.

- Integration of the multiple modes of transportation on a Mobility as a Service (MaaS) platform

- Reorganization of the public transport with particular emphasis on the public transport in the historic center

- The progressive introduction of electric buses in the public transport system

- Strengthening of the program that promotes the use of bicycles as an alternative mode of transportation

- Implementation of a compulsory Inspection and maintenance (I/M) program for all vehicles

The previous strategies were included in the Saltillo's 2020 PACMUN. This last term refers to the municipal climatic action plan, which is a program that was introduced in 2015 in Mexico by ICLEI-local governments for sustainability with the support of INECC (the Mexican national institution for ecology and climate change), and foreign agencies.

\section{Final Remarks}

In this work, a methodology to assess sustainable urban mobility in urban centers was proposed. It takes into consideration the unique circumstances of LATAM cities (mobility based on buses, spread cities located in mountainous regions, and low-income population living in the outskirts of the city). This methodology was applied to the city of Saltillo, which is a typical, medium size, LATAM city.

The proposed methodology evaluates five pillars that influence the sustainable mobility of people and goods within the city: (i) accessibility to mobility, (ii) government structure related to mobility, (iii) environmental impact of the transport system, and (iv) driving patterns. For each pillar, several categories were considered, and for each category, metrics of evaluation (key performance indicators- KPIs) were defined (Table 3). Finally, urban mobility is evaluated by comparing each $K P I_{i}$ with a reference value. The qualification of sustainable mobility is obtained as the average value of the normalized $K P I_{i}$ on a scale from 0 to $100 \%$.

This methodology is based on methodologies previously reported in the literature. It looks after a reproducible and objective method to evaluate sustainable mobility at a reduced cost by using state of the art in information technology. However, looking forward to a uniform, well-accepted, and eventually, in a standardized methodology to access sustainable mobility in any city, additional work is needed to resolve the following issues: (i) The identification of a reduced number of KPIs that genuinely capture the effects of the relevant categories on sustainable mobility. (ii) The KPIs should be evaluated through well-established procedures and based on data easy to obtain at a reduced incremental cost.

(iii) The establishment of appropriate reference values for each $K P I_{i}$.

We suggested the use of web map services to evaluate the infrastructure for mobility available in the city; the use of telematics data to evaluate the average speed and real fuel consumption; results from the air quality monitoring network to evaluate the city's air quality; and results from the inspection and maintenance program to evaluate the tailpipe emissions from the circulating vehicles. As a first approximation, reference values for 
each $K P I_{i}$ were obtained from cities similar to Saltillo that are considered as having a good performance on the corresponding category.

Further work is required to include in the methodology additional KPIs and reference values to evaluate the degree of smartness of the mobility in the city under assessment. Moreover, additional work is required to convert the mobility assessment methodology into an MRS (monitoring and reporting system) that continuously evaluates the effects on mobility of the strategies that the city's government is implementing.

Author Contributions: Conceptualization, J.I.H., S.S., T.F., X.G. and R.C.; methodology, J.I.H., S.S., T.F.; software, J.I.H., S.S., T.F., O.S.-G., A.E.M., D.A.A.; validation, J.I.H., S.S., T.F., X.G., R.C.; formal analysis, J.I.H., S.S., T.F., X.G.; investigation, J.I.H., S.S., T.F., O.S.-G., A.E.M., D.A.A.; resources, NA.; data curation, J.I.H., S.S., T.F., X.G., O.S.-G., A.E.M., D.A.A.; writing-original draft preparation, J.I.H., O.S.-G., A.E.M., D.A.A.; writing-review and editing, J.I.H., S.S., T.F., X.G., O.S.-G., A.E.M.; visualization, O.S.-G., A.E.M.; supervision, J.I.H.; project administration, J.I.H., S.S., T.F., X.G. All authors have read and agreed to the published version of the manuscript.

Funding: Not applicable.

Institutional Review Board Statement: Not applicable.

Informed Consent Statement: Not applicable.

Data Availability Statement: Exclude this statement.

Acknowledgments: This work was sponsored by the German Federal Ministry for the Environment, Nature Conservation, and Nuclear Safety; and CONACYT (Mexican Council for Science and Technology).

Conflicts of Interest: The authors declare no conflict of interest.

\section{References}

1. $\mathrm{CO}_{2}$ Emissions from Fuel Combustion-Overview; International Energy Agency: Washington, DC, USA, 2017.

2. Pérez, J.; de Andrés, J.M.; Borge, R.; de la Paz, D.; Lumbreras, J.; Rodríguez, E. Vehicle fleet characterization study in the city of Madrid and its application as a support tool in urban transport and air quality policy development. Transp. Policy 2018, 74, 114-126. [CrossRef]

3. Curl, A.; Nelson, J.; Anable, J. Does accessibility planning address what matters? A response to Derek Halden by Curl, Nelson and Anable. Res. Transp. Bus. Manag. 2012, 3, 84. [CrossRef]

4. The Sustainable Mobility Project; World Business Council for Sustainable Development (WBCSD): Geneva, Switzerland, 2002.

5. Kordej-De Villa, Ž. Human Smart Cities: Rethinking the interplay between design and planning. Privred. Kretanjua I Ekon. Polit. 2017, 25, 71-83.

6. Institute of Human Factors and Technology Management IAT. City Lab Kochi, India; Institute of Human Factors and Technology Management IAT: Stuttgart, Germany, 2020.

7. Joumard, R.; Gudmundsson, H. Indicators of Environmental Sustainability in Transport; European Commission. RECHERCHES No. R282. Available online: http:/ / cost356.inrets.fr (accessed on 13 October 2021).

8. Garau, C.; Masala, F.; Pinna, F. Benchmarking smart urban mobility: A study on Italian cities. In International Conference on Computational Science and Its Applications; Springer: Berlin/Heidelberg, Germany, 2015; pp. 612-623.

9. Camagni, R.; Gibelli, M.C.; Rigamonti, P. Urban mobility and urban form: The social and environmental costs of different patterns of urban expansion. Ecol. Econ. 2002, 40, 199-216. [CrossRef]

10. Frei, F. Sampling mobility index: Case study in Assis-Brazil. Transp. Res. Part A Policy Pr. 2006, 40, 792-799. [CrossRef]

11. Silva, A.N.R.D.; Costa, M.D.S.; Ramos, R.A. Development and Application of I_SUM: An Index of Sustainable Urban Mobility. In Proceedings of the Transportation Research Board (TRB) 89th Annual Meeting, Washington, DC, USA, 10-14 January 2010.

12. Machado, L. Índice de Mobilidade Sustentável para Avaliar a Qualidade de Vida Urbana: Estudo de caso Região Metropolitana de Porto Alegre-RMPA. Master's Thesis, Universidade Federal do Rio Grande do Sul. Faculdade de Arquitetura, Porto Alegre, Mexico, 2010.

13. Zito, P.; Salvo, G. Toward an urban transport sustainability index: A European comparison. Eur. Transp. Res. Rev. 2011, 3, 179-195. [CrossRef]

14. Jeon, C.M.; Amekudzi, A.A.; Guensler, R.L. Sustainability assessment at the transportation planning level: Performance measures and indexes. Transp. Policy 2013, 25, 10-21. [CrossRef]

15. Haghshenas, H.; Vaziri, M. Urban sustainable transportation indicators for global comparison. Ecol. Indic. 2012, 15, 115-121. [CrossRef] 
16. Patterson, Z.; Saddier, S.; Rezaei, A.; Manaugh, K. Use of the urban core index to analyze residential mobility: The case of seniors in Canadian metropolitan regions. J. Transp. Geogr. 2014, 41, 116-125. [CrossRef]

17. Reisi, M.; Aye, L.; Rajabifard, A.; Ngo, T. Transport sustainability index: Melbourne case study. Ecol. Indic. 2014, 43, 288-296. [CrossRef]

18. Moeinaddini, M.; Asadi-Shekari, Z.; Shah, M.Z. An urban mobility index for evaluating and reducing private motorized trips. Measurement 2015, 63, 30-40. [CrossRef]

19. Lopez-Carreiro, I.; Monzon, A. Evaluating sustainability and innovation of mobility patterns in Spanish cities. Analysis by size and urban typology. Sustain. Cities Soc. 2018, 38, 684-696. [CrossRef]

20. Morfoulaki, M.; Papathanasiou, J. Use of the sustainable mobility efficiency index (SMEI) for enhancing the sustainable urban mobility in Greek cities. Sustainability 2021, 13, 1709. [CrossRef]

21. Sampaio, C.; Macedo, E.; Coelho, M.C.; Bandeira, J.M. Economic and environmental analysis of measures from a Sustainability Urban Mobility Plan-Application to a small sized city. Transp. Res. Procedia 2020, 48, 2580-2588. [CrossRef]

22. Regmi, M.B. Measuring sustainability of urban mobility: A pilot study of Asian cities. Case Stud. Transp. Policy 2020, 8, 1224-1232. [CrossRef]

23. Nemoto, E.H.; Issaoui, R.; Korbee, D.; Jaroudi, I.; Fournier, G. How to measure the impacts of shared automated electric vehicles on urban mobility. Transp. Res. Part D Transp. Environ. 2021, 93, 102766. [CrossRef]

24. Sharifi, A. A typology of smart city assessment tools and indicator sets. Sustain. Cities Soc. 2020, 53, 101936. [CrossRef]

25. The Sustainable Mobility Project; World Business Council for Sustainable Development (WBCSD): Geneva, Switzerland, 2016.

26. Sustainable Urban Transport Index (SUTI); Economic and Social Commission for Asia and the Pacific (ESCAP): Bangkok, Thailand, 2018.

27. Union Internationale des Transports Publics UITP, Mobility in Cities Database. Available online: https://www.uitp.org/ publications / mobility-in-cities-database/ (accessed on 30 June 2021).

28. A Centre for Economics \& Business Research Exploration with Qualcomm, n.d. Urban Mobility Index. Available online: https://www.qualcomm.com/media/documents/files/urban-mobility-index-report.pdf (accessed on 30 June 2021).

29. The Future of Mobility 3.0. Reinventing Mobility in the Era of Disruption and Creativity. Available online: https://www.adlittle. com/en/insights/viewpoints/future-mobility-30 (accessed on 30 June 2021).

30. HERE. Urban Mobility Index. Available online: https:// urbanmobilityindex.here.com/ (accessed on 30 June 2021).

31. Deloitte Insights, The 2020 Deloitte City Mobility Index. Deloitte City Mobil. Index. Available online: https:/ / www2.deloitte. com/content/dam/insights/us / articles /4331_Deloitte-City-Mobility-Index/2020/DCMI_Methodology_2020_WEB.pdf (accessed on 30 June 2021).

32. Sustainable Urban Mobility Indicators (SUMI); Commission E: Brussels, Belgium, 2020.

33. Marchetti, D.; Oliveira, R.; Figueira, A.R. Are global north smart city models capable to assess Latin American cities? A model and indicators for a new context. Cities 2019, 92, 197-207. [CrossRef]

34. Aghaabbasi, M.; Moeinaddini, M.; Shah, M.Z.; Asadi-Shekari, Z. Addressing issues in the use of Google tools for assessing pedestrian built environments. J. Transp. Geogr. 2018, 73, 185-198. [CrossRef]

35. Altamirano-Avila, A.; Martínez, M. Urban sustainability assessment of five Latin American cities by using SDEWES index. J. Clean. Prod. 2020, 287, 125495. [CrossRef]

36. Análisis Diagnóstico de la Ciclovía y Movilidad no Motorizada en el Municipio de Saltillo; IMPLAN: Saltillo, Mexico, 2018.

37. Pinhate, T.B.; Parsons, M.; Fisher, K.; Crease, R.P.; Baars, R. A crack in the automobility regime? Exploring the transition of São Paulo to sustainable urban mobility. Cities 2020, 107, 102914. [CrossRef]

38. PurpleAir Inc. An Air Quality Monitoring Network Built on a New Generation of "Internet of Things" Sensors. PurpleAir Real-time Air Qual. Monit. Available online: https:/ / www2.purpleair.com/ (accessed on 9 August 2021).

39. Air Quality Index: A Guide to Air Quality and Your Health; United States Environmental Protection Agency: Washington, DC, USA, 2009.

40. Informe Annual; CFE Comision Federal de Electricidad: Mexico City, Mexico, 2019.

41. Quirama, L.F.; Giraldo, M.; Huertas, J.I.; Jaller, M. Driving cycles that reproduce driving patterns, energy consumptions and tailpipe emissions. Transp. Res. Part D Transp. Environ. 2020, 82, 102294. [CrossRef]

42. Giraldo, M.; Huertas, J.I. Real emissions, driving patterns and fuel consumption of in-use diesel buses operating at high altitude. Transp. Res. Part. D Transp. Environ. 2019, 77, 21-36. [CrossRef]

43. Mogro, A.E.; Huertas, J.I. Assessment of the effect of using air conditioning on the vehicle's real fuel consumption. Int. J. Interact. Des. Manuf. 2021, 1-5. [CrossRef]

44. Franco, V.; Kousoulidou, M.; Muntean, M.; Ntziachristos, L.; Hausberger, S.; Dilara, P. Road vehicle emission factors development: A review. Atmos. Environ. 2013, 70, 84-97. [CrossRef]

45. Mancilla, Y.; Araizaga, A.E.; Mendoza, A. A tunnel study to estimate emission factors from mobile sources in Monterrey, Mexico. J. Air Waste Manag. Assoc. 2012, 62, 1431-1442. [CrossRef]

46. Bishop, G.; Stedman, D.H. Measuring the emissions of passing cars. Accounts Chem. Res. 1996, 29, 489-495. [CrossRef]

47. Borken-Kleefeld, J.; Dallman, T. Remote Sensing of Vehicle Exhaust Emissions; International Council on Clean Transportation: Washington, DC, USA, 2018.

48. Secretaria de Medio Ambiente y Recursos Naturales, NOM-167-SEMARNAT; Diario Oficial de la Federación: Mexico City, Mexico, 2017. 
49. Clean Screening in Inspection and Maintenance Programs. Tech. Highlights 1-4; United States Environmental Protection Agency: Washington, DC, USA, 1998.

50. Huertas, J.; Mogro, A.; Mendoza, A.; Huertas, M.; Ibarra, R. Assessment of the reduction in vehicles emissions by implementing inspection and maintenance programs. Int. J. Environ. Res. Public Health 2020, 17, 4730. [CrossRef]

51. Huertas, J.I.; Mendoza, A.; Huertas, M.E.; Ibarra, R.; Mogro, A. Potential environmental impact of I/M programs in urban centers based on RSD monitoring campaigns. IOP Conf. Ser. Earth Environ. Sci. 2020, 489, 012015. [CrossRef]

52. Quirama, L.F.; Giraldo, M.; Huertas, J.I.; Tibaquirá, J.E.; Cordero-Moreno, D. Main characteristic parameters to describe driving patterns and construct driving cycles. Transp. Res. Part D Transp. Environ. 2021, 97, 102959. [CrossRef]

53. Municipio de Saltillo, Saltillo Segunda Ciudad Mexicana Con Mayor PIB Per Cápita en 2019. Available online: https: / saltillo gob.mx/saltillo-segunda-ciudad-mexicana-con-mayor-pib-per-capita-en-2019/ (accessed on 1 July 2021).

54. Consejo Nacional de Evaluación de la Política de Desarrollo Social, Ingreso Laboral per Cápita. Monit. y Estados. Available online: https:/ / www.coneval.org.mx/coordinacion/Paginas/principal.aspx (accessed on 23 November 2020).

55. Propuesta Ordenamiento del Sistema de Transporte Público de la Zona Conurbada de Saltillo; IMPLAN: Saltillo, Mexico, 2015.

56. Sistema de Indicadores de Movilidad Urbana; IMPLAN: Saltillo, Mexico, 2015.

57. Instituto Mexicano del Transporte, Red Nacional de Caminos. Represent. Cart. en formato Digit. y Georreferenciada la Red Nac. Caminos. Available online: https://www.gob.mx/imt/acciones-y-programas/red-nacional-de-caminos (accessed on 21 July 2021).

58. Estudio de Emisiones Vehiculares de la Ciudad de Saltillo Mediante la Técnica de Detección Remota; INECC Instituto Nacional de Ecología y Cambio Climático: Mexico City, Mexico, 2019; p. 52.

59. Proposal for a Network of Cycling Routes for the City of Saltillo; IMPLAN: Saltillo, Mexico, 2016.

60. INEGI Instituto Nacional de Estadística Geografía e Informática, Inventario Nacional de Viviendas. Saltillo. Available online: https:/ / www.inegi.org.mx/app/mapa/inv/ (accessed on 2 July 2021).

61. Gobierno del Estado de Coahuila de Zaragoza. Constitución Política del Estado de Coahuila de Zaragoza; Diario Oficial de la Federación: Mexico City, México, 1918.

62. Gobierno del Estado de Coahuila de Zaragoza. Ley de Transito y Transporte del Estado de Coahuila de Zaragoza; Periódico Oficial DOF: Mexico City, México, 1996.

63. Gobierno del Estado de Coahuila de Zaragoza. Ley para el Desarrollo e Inclusión de las Personas con Discapacidad del Estado de Coahuila de Zaragoza; Periódico Oficial DOF: Mexico City, México, 2013.

64. Plan Municipal de Desarrollo Urbano Saltillo; Gobierno Municipal de Saltillo: Saltillo, Mexico, 2019.

65. Gobierno Municipal de Saltillo. Reglamento de Tránsito y Transporte para el Municipio de Saltillo, Coahuila de Zaragoza; Diario Oficial de la Federación: Mexico City, México, 2015.

66. Gobierno del Estado de Coahuila de Zaragoza. Ley de Transporte y Movilidad Sustentable para el Estado de Coahuila De Zaragoza; Diario Oficial de la Federación: Saltillo, México, 2019.

67. Hacia la Consolidación del Centro Histórico de Saltillo; IMPLAN: Saltillo, Mexico, 2018.

68. Análisis de Movilidad Urbana en el Centro Histórico de Saltillo; IMPLAN: Saltillo, Mexico, 2016.

69. Guía de Recomendaciones para Mejora del Segmento de Ciclovía: Centro de Gobierno-Distribuidor Vial El Sarape; IMPLAN: Saltillo, Mexico, 2015.

70. Recomendaciones al Proyecto Denominado: Actualización Tecnológica del Parquímetros; IMPLAN: Saltillo, Mexico, 2015.

71. Guía de Diseño de Infrastructura Peatonal; IMPLAN \& Gobierno Municipal de Saltillo: Saltillo, Mexico, 2017.

72. PEMEX, Hoja De Datos De Seguridad HDS-PEMEX-TRI-SAC-7. Gasolinas Pemex Prem. y Pemex Magna. Available online: https://www.coursehero.com/file/50004634/HDS-SAC-Gasolinas-Premium-y-Magna-TRI-7-1-1pdf/ (accessed on 23 November 2020).

73. Pepper, G.T. Methods and System for Determining Consumption and Fuel Efficiency in Vehicles. U.S. Patent 7,774,130, 10 August 2010.

74. Ramírez, J.D.; Giraldo-Peralta, N.; Flórez-Ceron, D.; Rangel, V.; Mejía-Argueta, C.; Huertas, J.I.; Bernal, M. Eco-driving key factors that influence fuel consumption in heavy-truck fleets: A Colombian case. Transp. Res. Part D Transp. Environ. 2017, 56, 258-270. [CrossRef]

75. Programa de Gestión para Mejorar la Calidad del Aire del Estado de Coahuila de Zaragoza 2017-2026; SEMARNAT: Mexico City, Mexico, 2017.

76. Western, G. Guía de Elaboración y Uso de Inventario de Emisiones; INE-SEMARNAT: Mexico City, Mexico, 2005.

77. Jiménez-Palacios, L.J. Understanding and Quantifying Motor Vehicle Emissions with Vehicle Specific Power and TILDAS Remote Sensing; Massachusetts Institute of Technology: Cambridge, MA, USA, 1999.

78. Redes Urbanas y Servicios de Planeación, S.A. de C.V. Programa de Desarrollo Urbano de la Zona Metropolitana de Saltillo-Ramos Arizpe-Arteaga. Saltillo. 2012. Available online: http:/ /www.segucoahuila.gob.mx/admin/uploads/Documentos/modulo2 3/programa_de_desarrollo_urbano_de_la_zona_metropolitana_saltillo_ramos_arteaga.pdf (accessed on 9 August 2021). 
79. Montufar, P.; Huertas, J.I.; Cuisano, J. Driving cycle and emission factors in high-altitude cities: Riobamba case. In Proceedings of the 2020 IEEE ANDESCON, Quito, Ecuador, 13-16 October 2020; pp. 1-6. [CrossRef]

80. Banco Interamericano de Desarrollo, Programa Ciudades Emergentes y Sostenibles. Acompañando el Crecim. Sosten. las Ciudad. emergentes Am. Lat. y el Caribe. Available online: https:/ / publications.iadb.org/es/guia-metodologica-programa-de-ciudadesemergentes-y-sostenibles-tercera-edicion-anexo-de (accessed on 9 August 2021). 